Board of Governors of the Federal Reserve System

International Finance Discussion Papers

Number 1020

June 2011

\title{
Trade Credit and International Trade during the 2008-09 Global Financial Crisis
}

\author{
Brahima Coulibaly \\ Horacio Sapriza
}

Andrei Zlate

NOTE: International Finance Discussion Papers are preliminary materials circulated to stimulate discussion and critical comment. References to International Finance Discussion Papers (other than an acknowledgment that the writer has had access to unpublished material) should be cleared with the author or authors. Recent IFDPs are available on the Web at www.federalreserve.gov/pubs/ifdp/. This paper can be downloaded without charge from the Social Science Research Network electronic library at www.ssrn.com. 


\title{
Trade Credit and International Trade during the 2008-09 Global Financial Crisis*
}

\author{
Brahima Coulibaly
}

Federal Reserve Board

\author{
Horacio Sapriza
}

Federal Reserve Board

June 11, 2011

\author{
Andrei Zlate \\ Federal Reserve Board
}

\begin{abstract}
This paper studies the role of the credit crunch in the severe contraction of trade and economic activity at the height of the 2008-09 global financial crisis, using firm-level data from six emerging market economies in Asia. We construct firm-specific measures of global demand, which allow us to disentangle the effect of falling demand from that of financial constraints on sales. The results indicate that: (1) Although the fall in demand adversely affected the sales of all firms during the crisis, sales declined by less for firms with better pre-crisis financial conditions. (2) In the face of the decline in external financing opportunities, some firms relied more on trade credit from suppliers to supplement operating capital during the crisis, which allowed them to post relatively better sales. (3) Export-intensive firms with comparable financial vulnerability resorted less to trade credit as an alternative source of finance, and hence experienced sharper declines in sales than the domestically-oriented firms. These findings point to the presence of credit frictions among the factors that contributed to the disproportionately large decline in international trade during the crisis.
\end{abstract}

JEL classification: F14, F23, G32

Keywords: trade credit, 2008-09 financial crisis, emerging Asia, international trade.

\footnotetext{
${ }^{*}$ We are grateful to Shaghil Ahmed, Martin Bodenstein, Aitor Erce, Neil Ericsson, Julian di Giovanni, Benjamin Mandel, Patrice Robitaille, Katheryn Russ, Robert Vigfusson, as well as seminar participants at the 2011 North American Meeting of the Econometric Society, the XV CEMLA meeting at the Central Bank of Bolivia, the 2010 European Trade Study Group meeting at the University of Lausanne, and the Federal Reserve Board for helpful comments. We also thank Quoctrung Bui, Kavita Patel and Peter Weyand for excellent research assistance. Correspondence: Brahima.Coulibaly@frb.gov, Horacio.Sapriza@frb.gov and Andrei.Zlate@frb.gov, Division of International Finance, Board of Governors of the Federal Reserve System, Washington, D.C. 20551, U.S.A. The views in this paper are solely the responsibility of the authors and should not be interpreted as reflecting the views of the Board of Governors of the Federal Reserve System or of any other person associated with the Federal Reserve System.
} 


\section{Introduction}

The 2008-09 financial crisis had dramatic effects on the global economic activity. One of the most salient features was the decline in international trade relative to gross domestic product (GDP), which was unusually abrupt compared with past recessions for most economies, including for the emerging market economies that we study in this paper (Figure 1). ${ }^{1}$ Several transmission channels may help explain this unprecedented drop in international trade, including the steep reduction in global demand, as well as the significant tightening of external financing that reduced firms' operating capital and limited their ability to satisfy demand for their products. The effect of the decline in global demand on trade is well understood and documented. However, there has been relatively limited formal empirical analysis on the scarcity of external financing during the crisis as an additional factor that contributed to the collapse in trade and economic activity. ${ }^{2}$

This paper fills in this void by studying the effect of the change in external financing more generally, and trade credit in particular, on trade and economic activity during the recent global financial crisis. ${ }^{3}$ In our analysis, trade credit refers to the financing that firms receive from their suppliers in the form of delayed payments for the transfer of goods and services. ${ }^{4}$ Using firmlevel data from China, India, Indonesia, Malaysia, Taiwan and Thailand, we explore: (1) Whether financial constraints (i.e. reduced access to external financing in the form of bank loans and bond issuance) adversely affected firm-level sales during the crisis, after controlling for the deterioration in global demand. (2) Whether the ability of firms to partially replace external finance with trade credit from suppliers enhanced their relative performance during the crisis. (3) Whether the relative inability of export-intensive firms to use trade credit as an alternative source of finance contributed to the larger decline in sales experienced by these firms.

To disentangle the effect of financial constraints from the demand-driven reduction in sales during the crisis, we use two types of explanatory variables in our regression analysis. First, we

\footnotetext{
${ }^{1}$ See the WTO (2009)'s World Trade Report. Amiti and Weinstein (2009) also document that, while the cumulated GDP of a sample of 17 countries (that together account for 70 percent of the world's GDP and exports) fell 10 percent between the first quarter of 2008 and the first quarter of 2009, exports plunged as much as 28 percent.

${ }^{2}$ This paper highlights the presence of financial constraints among the factors that contributed to the decline in world trade during the 2008-09 crisis; it does not attempt to quantify the relative importance of the various factors that caused the decline in trade.

${ }^{3}$ In line with our results, the World Bank estimates that, although the decline in world trade between mid-2008 and mid-2009 was largely caused by reduced demand for exports, the reduction in the supply of trade finance accounted for about 15 percent of it (Auboin 2009).

${ }^{4}$ In contrast to "trade credit," the literature uses "trade finance" to refer to a broader range of short-term financing related to the international trade activities of firms, such as working capital loans, letters of credit and trade insurance provided by firms, banks or government agencies (see U.S. Department of Commerce, 2007).
} 
use the variation in firms' pre-crisis degree of financial vulnerability and reliance on various sources of finance, including trade credit, to explain their sales performance during the crisis. Second, we construct firm-specific measures of global demand, a novel approach that allows us to document the effect of financial frictions on sales while controlling for the variation in demand.

Our results can be summarized as follows: (1) Financial conditions contributed to the decline in sales for all firms, but sales declined by less for firms with better financial conditions prior to the crisis, such as those with more liquid assets and less exposure to external finance, especially short-term debt. Moreover, after controlling for pre-crisis financial characteristics, export-intensive firms recorded larger declines in sales than their domestically-oriented counterparts. (2) Trade credit declined by less for the financially-vulnerable firms, especially firms with more exposure to short-term debt before the crisis, suggesting that some firms relied more on trade credit to cope with the dire financial conditions during the crisis. In addition, firms that were able to replace external finance with trade credit during the crisis - predominantly domestic-oriented firms - experienced smaller declines in sales than firms that did not. (3) Exporters with comparable financial vulnerabilities had limited access to trade credit as an alternative source of finance, and hence experienced larger declines in sales. The results help explain the disproportionately larger effect of the credit crunch on international trade during the crisis.

Our results are not driven by differences in demand for domestic and export-oriented firms, or by differences in the firms' pre-crisis levels of inventories. We control for the effect of demand on firm-level sales in two ways: First, we implicitly control for demand by using industry, size and country fixed effects, since firms in the same industry and country of origin were likely to be affected by similar demand conditions. Second, we use an index of global demand constructed from firm-level data on export reliance, sector-level data on exports by destination, and real GDP growth across destinations as a proxy for the change in demand. We also control for the role of firms' inventories in offsetting the impact of financial constraints on sales. These results highlight the interaction between financial constraints and the real sector in propagating the effects of the global financial crisis. In particular, they document the presence of firm-specific credit constraints among the factors that led to the unprecedented drop in global trade during the crisis.

Our study adds to the sparse evidence on the role of trade credit and trade finance during financial crises. For instance, Chor and Manova (2009) show that the decline in U.S. imports during the 2008-09 global crisis was larger for countries of origin and sectors with adverse credit conditions, including limited reliance on trade credit. Amiti and Weinstein (2009) match bank with 
firm-level data for Japan, and document that trade finance received from banks played a key role in the transmission of financial shocks to exporting firms during the crisis that affected the country in the 1990s. Love et al. (2007) use firm-level data to document the reduction in the supply of trade credit during the Mexican devaluation in 1994-95 and the Asian crisis in 1997, but do not distinguish between the experience of exporting and non-exporting firms.

Other studies highlight the role of broadly-defined financial constraints on economic activity, especially international trade. Manova, Wei and Zhang (2009) use firm-level data for Chinese exporters from 2005 to show that multinational affiliates and joint ventures had better export performance than private domestic firms, especially in sectors with greater reliance on external finance and fewer hard assets to be used as collateral. Kalemli-Ozcan, Kamil and Villegas-Sanchez (2010) use firm-level panel data for six Latin American countries between 1990 and 2005 to account for the effect of financial constraints on firm-level sales and investment during crises. They highlight the existence of two sources of financial constraints, one arising from the decline in the supply of credit to firms, and the other arising from the firms' reliance on foreign-currency debt that reduced their net worth during depreciation episodes. Kolasa, Rubasek and Taglioni (2010) use Polish firmlevel data to show that foreign-owned firms proved more resilient during the 2008-09 crisis, which they argue was due to intra-group lending mechanisms supporting the credit-constrained affiliates. Finally, using data on French firms, Bricongne et al. (2010) argue that export losses were larger for the more financially-constrained firms; while large exporters were affected mostly on their intensive margin, many small exporters stopped exporting altogether.

In contrast to the papers mentioned above, we study the role of trade credit received from suppliers (rather than trade finance received from banks or foreign affiliates) measured at the firm level (rather than at the sector level) as an alternative source of external financing during the 2008-09 crisis. In addition to trade credit, we also examine the relationship between firms' financial vulnerability prior to the crisis (measured as the size of liquid assets and exposure to short-term debt) and their sales performance during the crisis, while also taking into account firms' reliance on exports and exposure to global demand. Due to our focus on firms from emerging Asia, the 2008-09 global financial crisis - which originated in advanced economies - can be viewed as an exogenous event in our analysis.

Our finding that financially-vulnerable firms (those with higher exposure to short-term debt before the crisis) substituted toward trade credit during the crisis is consistent with the literature on bank and trade credit channels. In an early study, Meltzer (1960) concludes that when liquidity 
conditions were tight, "firms with relatively large cash balances increased the average length of time for which [trade] credit was extended. And this extension of trade credit appears to have favored those firms against whom credit rationing is said to discriminate." More recently, Kohler, Britton and Yates (2000) use a panel of publicly-traded firms from the United Kingdom and find that, during recessions, firms with direct access to capital markets extended more trade credit and received less in return, thus making credit available to other firms that rely more on bank credit. In line with Meltzer (1960), they argue that there is a "trade credit channel" that offsets the traditional bank credit channel in the monetary economics literature. ${ }^{5}$

The rest of the paper is organized as follows. Section 2 describes the data, Section 3 describes the empirical specifications, and Section 4 discusses the findings and robustness analysis. Section 5 concludes.

\section{Data}

Our empirical analysis uses annual and quarterly data for about 7,200 publicly traded non-financial firms from six emerging Asian countries - China, India, Indonesia, Malaysia, Taiwan and Thailand - obtained from the Worldscope database. About one quarter of the firms in our sample with sales data for 2007 also reported exports for the same year $(1,765$ out of 7,227 firms $) .{ }^{6}$

The firm-level data display contours similar to those of the aggregate data (Figure 2). First, aggregate activity measured by real GDP or industrial output contracted significantly between 2008:Q3 and 2009:Q1 (top-left panel). The median firm-level output, measured by sales, displays a similar pattern (bottom-left panel). Second, global trade fell sharply during the global financial crisis: The top-middle panel shows the significant decline in exports between 2008:Q3 and 2009:Q1 for the countries in our sample. At the firm level, we measure exports as the median sales of exportintensive firms whose exports represent more than 50 percent of total sales (bottom-middle panel). The aggregate and firm-level exports data display similar contours, with significant declines at the height of the global financial crisis. Third, another notable feature of the crisis was the significant

\footnotetext{
${ }^{5}$ An important assumption behind the idea of the offsetting trade credit channel is that the adverse financial shock must cause the external finance premium to rise by more for bank-dependent firms than for firms with access to the capital market that provide trade credit. While a tightening of liquidity conditions may worsen firms' access to bank credit, those firms that can directly fund themselves in credit markets may step in to fill the financing gap, thus reducing the effect of the credit tightening on the economy.

${ }^{6}$ The firms reporting exports for 2007 account for similar shares (about 25 percent) of the cumulated total sales and total assets in our sample. A similar fraction of firms reported exports on average between 2005 and 2007 . Given our focus on international trade, we work with six emerging market economies where a reasonable number of firms report both exports and sales for the pre-crisis year (2007) in the Worldscope database (see Appendix A).
} 
deterioration in credit provision and an attendant run-up in the cost of capital. This feature is captured in the panels to the right by the growth of credit extended to the private sector at the aggregate level (top), and by the median external financing at the firm level (which is available at the annual frequency only, bottom panel).

The similarity in the patterns of aggregate and firm-level data provides reassurance for the use of micro data to understand the linkages between financial conditions, trade and economic activity during the global financial crisis. The richness of the micro data allows us to conduct the analysis while controlling for other factors that otherwise would have confounded estimation.

Using these micro data, we construct a cross-sectional data set as follows. (See Appendix $\mathrm{B}$ for a detailed description of the variables.) The contraction in firm-level activity during the financial crisis is measured by the percent decline in quarterly sales from peak (2008:Q3) to trough (2009:Q1). We construct the exports-to-sales ratio using data available at the annual frequency for 2007 (the pre-crisis year). For the baseline results, we treat firms reporting sales but not exports as non-exporters; in our robustness analysis, we use two alternative measures of export reliance, with similar results. The pre-crisis measures of financial vulnerability and liquidity consist of short-term debt and working capital, each normalized by total assets, as well as the quick ratio (the ratio of liquid assets to current liabilities).

Besides the standard forms of external and internal financing (measured as total external finance and retained earnings, each normalized by total assets), firms often rely on trade credit from suppliers to supplement operating capital. Thus, we use trade credit as one of the key variables in our study. We measure the stock of trade credit at the end of 2007 as the stock of accounts payable normalized by the cost of goods sold, following Love et al. (2007) and Levchenko et al. (2010). ${ }^{7}$

We use data for exports, short-term debt, quick ratio, working capital, external finance and retained earnings available at the annual frequency only, and data on sales and accounts payable available at the quarterly frequency. Thus, the data allow to study the link between firms' sales performance during the crisis measured at the quarterly frequency (as the percent change in sales between the peak and trough quarters) and a set of firm characteristics measured with annual data for the pre-crisis year (including export reliance, financial vulnerability, liquidity and reliance on various sources of finance in 2007). In an alternative specification, the data also allow to study the link between firms' access to trade credit during the crisis, measured as the change in

\footnotetext{
${ }^{7}$ We multiply the ratio between accounts payable and the cost of goods sold by 360 , and interpret the product as the number of days for which trade credit is received, as in Love et al. (2007).
} 
quarterly accounts payable between 2008:Q3 and 2009:Q1, and the pre-crisis indicators of financial vulnerability and export reliance measured at the annual frequency.

Firms covered by the Worldscope database report their financial indicators according to each country's fiscal year (FY), which coincides with the calendar year for all countries in our sample except for India and Thailand. To match the firm-level data with the period marked by the crisis, we have converted the fiscal years into calendar years by re-aligning the quarterly data for India (where FY 2009 started in April 2008) and Thailand (where FY 2009 started in October 2008). ${ }^{8}$ For the same reason, for India and Thailand, we have assigned the annual data reported for FY 2009 to calendar year 2008.

Out of the initial 7,200 firms, our econometric analysis is confined to the sub-sample of firms for which data are simultaneously available for the dependent and explanatory variables (see Tables 1-3). The sample size is restricted by the removal of outliers, which we replace with missing values: We exclude observations in both the top and bottom percentiles for external finance (which can be either positive or negative), and remove the bottom percentile for retained earnings and working capital. For the exports-to-sales ratio, short-term debt, the quick ratio, and accounts payable (which have a lower bound at zero), we exclude observations in the top percentiles only.

In addition to firm-level data from Worldscope, we use annual data on exports by destination detailed at the two-digit sector level (provided by Comtrade), as well as quarterly data on real GDP for the countries of origin and destination to construct an index of global demand, as described in the next section.

\section{Empirical Methodology}

We study the behavior of firm-level sales and trade credit received during the crisis in a crosssectional framework, with the peak-to-trough decline in sales and trade credit as dependent variables in alternative specifications. First, we aim to explain the sales performance during the crisis using the variation in firm-specific financial characteristics measured prior to the crisis, such as the degree of financial vulnerability, liquidity, and reliance on external financing that became expensive and difficult to obtain during the crisis. Second, we examine the characteristics of firms that increased their use of trade credit as an alternative source of financing, and also investigate the effect of this substitution on firms' sales during the crisis. In both specifications, we control for the change in

\footnotetext{
${ }^{8}$ For India, the first quarter of FY2009 became the second quarter of calendar year 2008. For Thailand, the first quarter of FY2009 became the fourth quarter of calendar year 2008.
} 
demand during the crisis.

\subsection{Model 1: Determinants of Firm Performance}

In the first model, we explore the link between firm performance during the crisis, expressed as the percent change in firm sales between 2008:Q3 and 2009:Q1 (the dependent variable), and firmspecific characteristics such as financial vulnerability, reliance on external financing, export reliance measured before the crisis (year 2007), as well as exposure to demand conditions during the crisis. This econometric specification allows to measure the peak-to-trough change in sales using quarterly data, and at the same time to use explanatory variables computed from data available at the annual frequency only. Given that the downturn and subsequent recovery of economic activity in emerging market economies occurred over just a few quarters, the use of annual data to measure the peak-totrough decline in sales would have understated the effect of the crisis on sales and the corresponding variation across firms.

We use the following econometric specification in a cross-sectional framework:

$$
\begin{aligned}
\% \Delta \text { Sales }_{i} & =\alpha+\beta_{1} * \text { FinVuln }_{2007, i}+\beta_{2} * \text { FinSource }_{2007, i}+\beta_{3} * \operatorname{Exp}_{\text {Sales }} 2007, i \\
& +\beta_{4} * \text { Demand }_{i}+ \\
& +\sum_{s} \delta_{s} * \operatorname{Industry}_{s, i}+\sum_{v} \delta_{v} * \operatorname{Size}_{v, i}+\sum_{c} \delta_{c} * \text { Country }_{c, i}+\varepsilon_{i},
\end{aligned}
$$

where the set of explanatory variables includes:

1. Indicators reflecting the degree of financial vulnerability and liquidity across firms measured at the onset of the crisis (FinVuln $2007, i)$. These are: (i) the stock of short-term debt normalized by total assets; (ii) in separate specifications, the quick ratio (the sum of cash, cash equivalents and net receivables divided by current liabilities) and working capital (the difference between current assets and current liabilities normalized by total assets) as alternative measures of financial liquidity.

2. Measures of firms' reliance on external and internal sources of finance prior to the crisis $\left(\right.$ FinSource $\left._{2007, i}\right)$. For this purpose, we use total external finance and retained earnings in 2007, each normalized by total assets. We also use the amount of trade credit received form suppliers in the pre-crisis year, measured as the stock of accounts payable in 2007 normalized by the cost of goods sold.

3. Firms' export status, measured as the exports-to-sales ratio in 2007. 
4. We use dummy variables to isolate the industry, size, and country effects. We assign firms to 24 industry groups provided by the Worldscope database, after excluding financial firms from our sample. We also rank firms in three size categories based on their total assets in 2007 (see Appendix B).

5. Indicators of demand. In one specification, we implicitly control for demand through the industry, size and country fixed effects, as discussed in the introduction. In an alternative specification, we use a firm-specific index of global demand, which we construct as described below.

Demand Index We construct the index of demand as a function of the firms' exports-tosales ratio, the sector-specific exposure to various foreign destinations, and real GDP growth across destinations as a proxy for the change in demand. Since the firm-level export data is not detailed by destination, we use sector-level data on exports by destination detailed at the 2-digit level for each country of origin (provided by Comtrade SITC rev.3) to approximate firms' exposure to foreign destinations. ${ }^{9}$ For each sector and country of origin, we compute the shares of 31 export destinations for 2007. On average, the 31 destinations comprised more than 90 percent of our countries' exports in 2007. ${ }^{10}$ Thus, we assign the sector-specific external demand to firms according to their primary sector of activity, country of origin, and firm-specific degree of export reliance.

The demand index $\left(\mathrm{DI}_{i s c}\right)$ for firm $i$ in sector $s$ from country of origin $c$ is a weighted average of the change in domestic and external demand between 2008:Q3 and 2009:Q1, with the weights given by the firm-specific exports-to-sales ratio $\left(\mathrm{Exp} / \mathrm{Sales}_{i}\right)$ in 2007:

$$
\mathrm{DI}_{i s c}=\left(1-\operatorname{Exp} / \mathrm{Sales}_{i}\right) \times \% \Delta \mathrm{GDP}_{c}+\operatorname{Exp} / \mathrm{Sales}_{i} \times \sum_{d}\left(w_{d s c} \times \% \Delta \mathrm{GDP}_{d}\right) .
$$

In equation (2), we use the real GDP growth between 2008:Q3 and 2009:Q1 in country of origin $c$ as a proxy for domestic demand. We also use the average real GDP growth between 2008:Q3 and 2009:Q1 across the 31 foreign destinations as a proxy for external demand, weighted by the shares $w_{d s c}$ of each destination $d$ in the exports of sector $s$ from country of origin $c$ in 2007 .

\footnotetext{
${ }^{9}$ We have computed the demand index for Taiwan using Malaysia's sector-specific export shares by destination, since Comtrade does not provide export data for Taiwan. We obtain similar results when using trade data from China, Indonesia or Thailand to compute the demand index for Taiwan.

${ }^{10}$ We have repeated the exercise with the export shares by destination averaged over 2005-2007, and obtained similar results.
} 


\subsection{Model 2: Substitution Across Sources of Finance}

In the second model, we explore the firms' ability to substitute across various sources of finance during the crisis year (2008) as a strategy to relax their financial constraints and improve sales performance. To this end, we use the dynamic trade-off between the change in trade credit and external financing received during the crisis as a new dimension of firm heterogeneity, in addition to the static financial indicators measured prior to the crisis included in the specification in equation (1), in order to explain the change in sales during the crisis.

Figure 3 illustrates the trade-off between external finance and new trade credit received in 2008 by the firms in our sample. On the horizontal axis, the amount of external finance (normalized by total assets) measures the flow of firm financing from outside sources in 2008, such as the issuance and/or retirement of stock and debt. Thus, negative values of external finance correspond to firms that repurchased equity or experienced declines in their outstanding debt during the crisis. On the vertical axis, the difference in the stock of accounts payable between 2007 and 2008 normalized by the cost of goods sold shows the change in trade credit received from suppliers during the crisis. Positive values on the vertical axis correspond to firms that obtained more trade credit in 2008 relative to the previous year. ${ }^{11}$

In Figure 3, we classify firms across the four quadrants defined by the zero lines. We label the quadrants as 1-4, starting with quadrant 1 in the North-West and moving clockwise towards quadrant 4 in the South-West:

1. Firms in quadrant 1 posted an increase in trade credit received from suppliers but negative external financing, thus replacing external finance with trade credit during the crisis.

2. Firms in quadrant 2 experienced both an increase in trade credit and positive external financing, thus becoming less constrained along both dimensions.

3. Quadrant 3 includes firms with declines in trade credit but positive external financing, thus substituting trade credit with external finance in the crisis year.

4. Finally, quadrant 4 consists of firms with reduced access to both sources of finance in 2008 .

In order to study the extent to which substitution between external finance and trade credit affected sales during the crisis, we add a set of dummy variables (Quad 1-3) to the specification

\footnotetext{
${ }^{11}$ In Figure 3, we are constrained to using data on external finance available at the annual frequency only.
} 
described by equation (1). The dummy variables reflect the firms' distribution across the first three quadrants in Figure 1.

$$
\begin{aligned}
\% \Delta \text { Sales }_{i} & =\alpha+\beta_{1} * \text { FinVuln }_{2007, i}+\beta_{2} * \text { FinSource }_{2007, i}+\beta_{3} * \operatorname{Exp}_{\text {Sales }_{2007, i}}+\beta_{4} * \operatorname{Demand}_{i}+ \\
& +\sum_{q=1,2,3} \theta_{s} * \operatorname{Quad}_{q, i}+\sum_{s} \delta_{s} * \text { Industry }_{s, i}+\sum_{v} \delta_{v} * \operatorname{Size}_{v, i}+\sum_{c} \delta_{c} * \operatorname{Country}_{c, i}+\varepsilon_{i}
\end{aligned}
$$

On average, after controlling for financial characteristics, demand, industry, size and country, we expect firms in quadrant 1 to outperform their counterparts in quadrant 4, since their improved access to trade credit should offset, at least partially, the reduced access to external finance. We also expect firms in quadrant 2 to outperform those in other quadrants. Finally, firms in quadrant 3 should fare better than those in quadrant 4.

\subsection{Model 3: Determinants of Trade Credit}

In the third model, we study the behavior of trade credit that firms received during the crisis. In particular, we ask: (1) What are the characteristics of firms that received more trade credit during the crisis? (2) What was the experience of exporters?

$$
\begin{aligned}
\Delta\left(\frac{\text { Payables }}{C G S}\right)_{i} & =\alpha+\beta_{1} * \text { FinVuln }_{2007, i}+\beta_{2} * \text { FinSource }_{2007, i}+\beta_{3} * \operatorname{Exp}_{\text {Sales }_{2007, i}}+\beta_{4} * \operatorname{Demand}_{i}+ \\
& +\sum_{s} \delta_{s} * \operatorname{Industry}_{s, i}+\sum_{l=2,3} \delta_{l} * \operatorname{Size}_{l, i}+\sum_{c} \delta_{c} * \operatorname{Country}_{c, i}+\varepsilon_{i}
\end{aligned}
$$

In the specification described by equation (4), we use quarterly data to construct the dependent variable, which is the peak-to-trough change in accounts payable normalized by the four-quarter sum of the cost of goods sold between 2008:Q3 and 2009:Q1. The explanatory variables consist of annual indicators of financial vulnerability, dependence on various sources of finance, export reliance in 2007, exposure to demand conditions, as well as the control dummies for industry, size and country described in section 3.1 above. 


\section{Results}

\subsection{Baseline Results}

Model 1: Determinants of Firm Performance Table 1 shows the baseline results for specification (1): In addition to the deterioration in global demand, the firm-specific financial conditions prior to the crisis affected sales performance during the crisis. Thus, firms with greater financial liquidity ex-ante experienced a smaller drop in sales, as evidenced by the positive and significant coefficients on working capital in columns (1) and (3). Similarly, the results in columns (2) and (4), which use the quick ratio as an alternative measure of liquidity, also indicate that firms with greater liquidity before the crisis experienced a relatively smaller decline in sales during the crisis. Differences in the firms' reliance on various sources of finance also affected sales: Firms with larger exposure to external financing prior to the crisis experienced a sharper drop in sales during the crisis, as shown by the corresponding coefficients in all columns of Table 1.

The coefficient on the demand index (columns 3 and 4) is positive and statistically significant, showing that the decline in firm-specific sales was in part associated with the fall in the global demand relevant to each firm. It is notable, however, that even after controlling for the decline in global demand, the firm-specific indicators of financial liquidity and reliance on external finance prior to the crisis are statistically significant and have the expected signs, as discussed above. The results suggest that, in addition to demand, financial conditions contributed to the decline of firm-level sales during the crisis.

Finally, while controlling for demand, exporting firms experienced a relatively more severe deterioration in sales than domestically-oriented firms. ${ }^{12}$ This result is consistent with the outsized decline in trade relative to GDP observed for the aggregate data shown in Figure 1.

Model 2: Substitution across Sources of Finance Although greater reliance on external finance prior to the crisis disrupted sales, the firms' ability to substitute external financing with trade credit during the crisis enhanced their sales performance. Table 2 shows the regression results for the specification in equation (3), which includes the substitution quadrants. The coefficient on quadrant 1 is positive and statistically significant across all columns, suggesting that firms that

\footnotetext{
${ }^{12}$ Out of the 7,200 firms with data on sales in our sample, about a quarter report either zero or positive exports for 2007; their median exports-to-sales ratio is 25 percent, and the average is 29 percent. For the baseline results, we assume that firms reporting sales but not exports are non-exporters, and assign them an exports-to-sales ratio equal to zero. In the robustness analysis, we relax this assumption by exploring a couple of imputation methods to construct the export status of these firms.
} 
were able to increase trade credit experienced a smaller decline in sales (by about 6 to 7 percentage points less) relative to firms in quadrant 4 (which experienced a reduction in both trade credit and external finance during the crisis). The coefficient on quadrant 3 is not statistically significant firms with less trade credit but more external finance did not fare better than firms with less access to both sources of finance - a result which highlights the importance of the trade credit dimension in understanding the sales performance across firms. Thus, the ability to substitute away from external finance towards trade credit enhanced sales, but the reverse was not true, possibly owing to the more onerous nature of external finance at times of financial turmoil. Finally, as expected, firms in quadrant 2 (which obtained more trade credit from suppliers and more external financing) experienced a smaller decline in sales relative to the firms in quadrant 4 (by about 9 to 10 percentage points less).

The pre-crisis financial indicators are statistically significant and have the expected sign, in line with our previous results. Firms that were less financially liquid (less working capital, smaller quick ratio) and more financially vulnerable prior to the crisis (greater reliance on short-term debt) performed worse than the average (columns 1-4). On the contrary, firms with greater reliance on trade credit from suppliers before the crisis fared better (columns 1 and 2).

Interestingly, once we control for the substitution between external financing and trade credit, the coefficient on the export-to-sales ratio becomes statistically insignificant (columns 1-4 in Table 2 ), suggesting that the relatively poor sales performance of export-oriented forms can be attributed to their lower ability to use trade credit. Indeed, out of the firms in quadrants 1 and 2 (firms that received more trade credit during the crisis), only 5 percent were export-intensive firms (with exports representing at least half of total sales), compared to as much as 8 percent of firms in quadrants 3 and $4 .^{13}$

Why would firms in financial distress receive trade credit from suppliers as an alternative form of finance? First, by extending trade credit, firms that regularly trade with each other diminish the cost of handling cash and invoices, as well as other administrative and payment costs. Ferris (1981) and Laffer (1970) provide early theoretical explanations for the use of trade credit based on this transaction motive. Second, the financing theory of trade credit argues that suppliers have a financing advantage over other credit providers (such as banks) due to the familiarity with the

\footnotetext{
${ }^{13}$ Overall, 6.5 percent of the firms in Figure 3 had exports accounting for more than half of sales in 2007. Similarly, if export-intensive firms are defined as firms with exports accounting for at least three quarters of total sales in 2007, the fraction of exporters across all quadrants was 3.9 percent; only 3.1 percent of the firms in quadrants 1 and 2 were exporters, compared to 4.6 percent of the firms in quadrants 3 and 4 .
} 
credit-worthiness of their customers (Schwartz, 1974). Third, suppliers also have an advantage in enforcing debt repayments, especially if they can credibly threaten to cut off future supply and the buyer has few alternative sources to purchase production inputs. Fourth, suppliers also have the advantage of a readily available network for reselling the collateralized goods in case of default.

Model 3: Determinants of Trade Credit Given that increased access to trade credit improved sales performance, the next set of results shed light on the characteristics of firms that were able to use more trade credit as an alternative source of finance during the crisis, based on the specification in equation (4). Table 3 shows the link between the change in trade credit and firm-specific indicators of financial vulnerability and export reliance measured prior to the crisis.

First, the more financially-vulnerable firms increased their use of trade credit during the crisis, as shown by the coefficient on short-term debt, which is positive and statistically significant in all columns. The result indicates that some of the financially-vulnerable firms used more trade credit as an alternative form of finance, likely due to the fact that their short-term debt matured and became difficult to rollover during the crisis. One possible explanation for this result is that suppliers became willing to extend trade credit to financially-constrained firms in order to maintain their customer base. Arguably, the close ties between suppliers and customer firms facilitated this type of lending compared to bank lending, as explained earlier.

Second, the more export-oriented firms were less able to use trade credit as an alternative source of finance. In all columns of Table 3, the results show a negative and statistically-significant relationship between the export share of sales in 2007 and the peak-to-trough change in trade credit during the crisis. Notably, the pattern holds even after using the index of global demand in columns 3 and 4. This result is consistent with the uneven distribution of export-oriented firms across the four quadrants in Figure 3, as discussed above. The finding suggests that export-intensive firms experienced less access to trade credit as an alternative source of finance, which in turn exacerbated the decline in international trade at the height of the financial crisis.

The headline results described above are subject to some caveats, which we address in the robustness analysis in the next section.

\subsection{Robustness Analysis}

Exports-to-sales ratio computed from logit model (Tables 4-6) In the analysis so far, we assumed that firms reporting sales but not exports for 2007 were non-exporters, and thus we 
assigned a value of zero to their exports-to-sales ratio. There is a possibility that some exporters may fail to report exports data, in which case assigning zero values to their exports-to-sales ratio could be problematic.

To ensure that our results are not driven by this assumption, we re-estimate our specifications from Models 1 and 2 (see equations 1 and 3) with an alternative measure of export reliance, using the following approach. First, we estimate a logit model for the sub-set of firms in our sample that reported either positive or zero exports for 2007. The dependent variable is the exporting status (exporter vs. non-exporter) and the predictor variable is the value of total assets in 2007 as a proxy for firm size, following the well-established empirical result from previous studies that exporting firms are larger and more productive than their domestically-oriented counterparts (Bernard et al., 2006). We also use fixed effects for industry and country of origin. The results from the logit specification are presented in Table 4. The slope coefficient for total assets is positive and statistically significant, showing that the probability of the firm being an exporter increases with firm size.

Second, we use the logit estimates to compute the probability of exporting as a function of firm size for the firms in our sample, including for firms that did not report exports but reported total assets for $2007 .^{14}$

Third, we use the resulting export probabilities as a proxy for export status and re-estimate Models 1 and 2. We also re-compute the global demand index using the new proxy for the exportsto-sales ratio. The results, presented in Tables 5 and 6, are largely similar to those in Tables 1 and 2, confirming that the assumption of zero exports for the missing observations does not materially affect our baseline results: The coefficients on pre-crisis indicators of financial liquidity are positive and statistically significant, while those on external finance (Table 5) and short-term debt (Table 6) are negative and significant. In addition, in Table 6, the coefficients on quadrants 1 and 2 are positive and statistically significant, showing that firms substituting external finance with trade credit during the crisis experienced a smaller decline in sales.

Constructing the export status for non-reporting firms from the logit model has the advantage that it generates variation in the exports-to-sales ratio using a reasonable economic assumption (i.e. export status depends on firms size). One possible limitation of this approach arises from the inability to determine the properties of the second-stage estimator, which depend on the extent to which the sub-sample of firms reporting exports (used in the logit, first-stage estimation) is

\footnotetext{
${ }^{14}$ Usingt the logit estimates, we compute the exporter probability as $\operatorname{prob}(i=\operatorname{exporter})=\exp \left(X_{i} \beta\right) /\left[1+\exp \left(X_{i} \beta\right)\right]$.
} 
representative of the entire sample of firms used in the second-stage regression. However, we do not believe that this limitation reverses our results. To be sure, we perform an additional robustness check by imputing the firm-level export status from sector-level averages, with similar results (described below).

Exports-to-sales ratio from sector averages (Tables 7-9) $\quad$ On a country-by-country basis, we assign the average exports-to-sales ratio computed at the 2-digit sector level to the firms in that sector that have missing export observations for 2007. We use the sector-level average ratios to replace the missing export observations at the firm level only for sectors in which at least three firms reported exports for each country. ${ }^{15}$ We keep the original exports-to-sales ratio values for firms that reported zero or positive exports.

The results for the determinants of sales performance, provided in Tables 7 and 8, are similar to those in Tables 1 and 2, and again show that the zero-export assumption for missing observations does not affect our baseline results. Similarly, for the characteristics of firms that used more trade credit during the crisis, the results in Table 9 are in line with the baseline results shown in Table 3.

Inventories (Table 10) One potentially important variable missing from the headline analysis is the level of firms' inventories. Inventories play an important role in meeting demand when production is disrupted. During the financial crisis, firms with production constrained by the dire financial conditions could have drawn on inventories to fulfill some or all of the demand for their products. In this case, financial conditions would have a smaller effect on sales. We reestimate the specification for Model 2 while controlling for the inventories-to-sales ratio measured in 2007. Indeed, the results in Table 10 show positive and statistically significant coefficients on the inventories-to-sales ratio (columns 1 and 3): Firms with higher levels of inventories relative to sales prior to the crisis experienced a relatively smaller decline in sales during the crisis. In addition, the specifications in columns (2) and (4) interact the inventories-to-sales with the financial variables already discussed. The coefficients on the interactions with the quick ratio and external finance are statistically significant and have the expected signs: The sales of firms with higher pre-crisis levels of inventories relative to sales were less constrained by their liquidity position or reliance on external finance. These results point to an important role of inventories in alleviating, but not

\footnotetext{
${ }^{15}$ We obtain similar results when the average exports-to-sales ratio is computed at the 3-digit sector level, but the number of observations declines significantly due to the prevalence of sectors in which less than three firms report exports in each country.
} 
eliminating, the effect of financial constraints on performance, as our benchmark results indicate.

Sample composition (Table 11) The sample used to estimate the specification in Model 2 (see Table 2) is larger than the sample used to estimate Model 3 (see Table 3 ) because accounts payable (the dependent variable in Model 3) are reported only by a subset of firms. To insure that our results are not affected by changes in the sample composition across the two models, we repeat the estimation of Model 2 while restricting the sample of firms to the subset that report both sales and accounts payable at the quarterly frequency. The new results in Table 11 show that sample composition has little effect on our main results. The coefficients on the quadrant dummies are still positive and statistically significant, and their magnitude is comparable to that from the baseline results in Table 2. This finding re-enforces our earlier results that firms that accessed more trade credit when external financing became scarce performed relatively better during the crisis. In addition, firms with greater exposure to external finance prior to the crisis fared worse, whereas those with more reliance on retained earnings or trade credit fared better.

Country effect (Tables 12 and 13) Last, we assess whether the results of the study are driven by any particular country in the sample. To this end, we re-estimate column (2) of Table 1 and column (2) of Table 3 by excluding one country at a time from the sample. The results are

presented in Tables 12 and 13, respectively. For example, the specification in column (1) excludes China; in column (2) we exclude India, etc. Overall the main results are little changed.

\section{Conclusions}

We explore the extent to which financial conditions contributed to the decline in firms' sales at the height of the 2008-09 global financial crisis using micro data from six emerging market economies, while controlling for firm-specific demand factors. We find that financial conditions adversely affected sales during the crisis, and that the use of trade credit played an important role in the relative performance of firms. In particular, when financing conditions deteriorated, the more financially-vulnerable firms turned to trade credit from suppliers as a supplement to standard forms of financing. In addition, firms that were able to replace external finance with trade credit had better sales performance. In contrast to domestically-oriented firms, export-intensive firms with comparable financial vulnerability relied less on trade credit as an alternative source of finance, and experienced sharper declines in sales. These results provide an explanation for the disproportionate 
decline in global trade during this recent crisis.

Our findings have implications for the design of policy to cushion the effect of future financial crises. Policymakers and firms would be well-advised to facilitate the development of trade credit as an additional source of financing when financial and credit markets become impaired. Along these lines, an interesting topic for future research would be to further understand the factors that determine the use or extension of trade credit between firms and, in particular, whether there are impediments to the cross-border flow of trade credit that prevent export-oriented firms from using this form of financing to the same extent as their domestic-oriented counterparts. 


\section{References}

[1] Amiti M. and D. Weinstein, 2009. "Exports and Financial Shocks," mimeo, Columbia University and FRB New York.

[2] Aubion, M., 2009. "Boosting the availability of trade finance in the current crisis: Background analysis for a substantial G20 package," CEPR Policy Insight No. 35, June.

[3] Bernard, A.B., J.B. Jensen, S.J. Redding, and P.K. Schott, 2007. "Firms in International Trade," Journal of Economic Perspectives, vol. 21(3), pp. 105-130.

[4] Bricongne, J.C., L. Fontagne, G. Gaulier, D. Taglioni and V. Vicard, 2010. "Firms and the global crisis: French exports in the turmoil," mimeo, Banque de France and the European Central Bank.

[5] Chor, D. and K. Manova, 2009. "Off the Cliff and Back? Credit Conditions and International Trade during the Global Financial Crisis," mimeo, Stanford University, December.

[6] Ferris, J.S., 1981. "A Transactions Theory of Trade Credit Use," Quarterly Journal of Economics, vol. 96(2), pp. 243-70, May.

[7] Love, I., L. Preve and V. Sarria-Allende, 2007. "Trade Credit and Bank Credit: Evidence from Recent Financial Crises," Journal of Financial Economics 83(2007), pp. 453-469.

[8] Levchenko, A., L. Lewis and L. Tesar, 2010. "The Collapse in International Trade During the 2008-2009 Financial Crisis: In Search of the Smoking Gun,” mimeo, University of Michigan.

[9] Kalemli-Ozcan, S., Herman Kamil and Carolina Villegas-Sanchez, 2010. "What Hinders Investment in the Aftermath of Financial Crises: Insolvent Firms or Illiquid Banks?," NBER Working Papers 16528.

[10] Kohler, M., E. Britton and T. Yates, 2000. "Trade credit and the monetary transmission mechanism," Bank of England Working Papers, No. 115.

[11] Kolasa, M., M. Rubaszek and D. Taglioni, 2010. "Firms in the great global recession: The role of foreign ownership and financial dependence," mimeo, Central Bank of Poland and the European Central Bank. 
[12] Laffer, Arthur B., 1970. "Trade Credit and the Money Market," Journal of Political Economy, vol. 78(2), pp. 239-67, March-April.

[13] Manova, K., Shang-Jin Wei and Zhiwei Zhang, 2009. "Firm Exports and Multinational Activity under Credit Constraints," mimeo, Stanford University.

[14] Meltzer, A., 1960. "Mercantile Credit, Monetary Policy, and Size of Firms," Review of Economics and Statistics, vol. 42(4), pp. 429-437, November.

[15] U.S. Department of Commerce, 2007. "Trade Finance Guide: A Quick Reference for U.S. Exporters," U.S. International Trade Administration.

[16] WTO (World Trade Organization), 2009. "World Trade Report," July. 


\section{A Exports Data by Country}

We summarize the number of firms reporting exports and sales for 2007 in the table below.

\begin{tabular}{|l|l|l|l|l|l|l|}
\hline \# firms reporting: & China & India & Indonesia & Malaysia & Thailand & Taiwan \\
\hline 2007 sales & 2,027 & 1,994 & 304 & 942 & 451 & 1,509 \\
\hline 2007 exports & 115 & 1,064 & 78 & 45 & 45 & 418 \\
\hline
\end{tabular}

\section{B Definitions of Variables}

Exports: Revenues generated from the shipment of merchandise to another country for sale.

External Finance: Company financing from outside sources. It includes the issuance and retirement of stock and debt.

Firm Size: We use total assets to construct dummy variables for firm size. Firms with assets in the top 33 percent of the distribution are considered large; those in the bottom 33 percent are small; the remaining firms are medium size.

Industry Group: We construct dummy variables at the two-digit level for the industry groups provided by Worldscope, described below.

\begin{tabular}{|l|l|l|}
\hline 1300 AEROSPACE & 3700 ELECTRICAL & 6100 PAPER \\
1600 APPAREL & 4000 ELECTRONICS & 6700 RECREATION \\
1900 AUTOMOTIVE & 4300 FINANCIAL & 7000 RETAILERS \\
2200 BEVERAGES & 4600 FOOD & 7300 TEXTILES \\
2800 CONSTRUCTION & 4900 MACHINERY \& EQUIPMENT & 7600 TOBACCO \\
3100 DIVERSIFIED & 5200 METAL PRODUCERS & 7900 TRANSPORTATION \\
3400 DRUGS, COSMETICS \& HEALTH CARE & 5800 OIL, GAS, COAL \& RELATED SERVICES & 8500 MisCELLANEOUS \\
\hline
\end{tabular}

Inventories: Represent tangible items or merchandise net of advances and obsolescence acquired for either (1) direct resale or (2) inclusion in the production of finished goods for sale in the normal course of operation. 
Quick Ratio: (Cash \& Equivalents + Net Receivables) / Total Current Liabilities.

Retained Earnings: Accumulated after-tax earnings of the company that have not been distributed as dividends to shareholders or allocated to a reserve account.

Sales: Gross sales and other operating revenue less discounts, returns and allowances. It includes franchise sales, consulting fees, service income, etc.

Short-Term Debt: Portion of debt payable within one year, including current portion of long term debt and sinking fund requirements of preferred stock or debentures.

Total Assets: Sum of total current assets, long-term receivables, investment in unconsolidated subsidiaries, other investments, net property plant and equipment, etc.

Total Current Liabilities: Debt or other obligations that the company expects to satisfy within one year. It includes accounts payable, short term debt, notes payable, current portion of long term debt, all accrued expenses, other current liabilities, income taxes payable, dividends payable, etc.

Working Capital: Difference between total current assets and total current liabilities normalized by total current assets. 


\section{Table 1. Determinants of Firm Performance (Sales):}

\section{Baseline Results}

Dependent variable: \% Change in Sales, 2008:Q3-2009:Q1

\begin{tabular}{|c|c|c|c|c|}
\hline VARIABLES & (1) & (2) & (3) & (4) \\
\hline Working Capital/Assets 2007 & $\begin{array}{l}7.855 * * \\
(3.252)\end{array}$ & & $\begin{array}{c}14.88 * * * \\
(3.573)\end{array}$ & \\
\hline Quick ratio 2007 & & $\begin{array}{c}1.242 * * * \\
(0.395)\end{array}$ & & $\begin{array}{c}1.781 * * * \\
(0.430)\end{array}$ \\
\hline Short-term debt/Assets 2007 & $\begin{array}{l}-7.804 \\
(5.323)\end{array}$ & $\begin{array}{l}-6.971 \\
(4.891)\end{array}$ & $\begin{array}{l}-1.097 \\
(5.807)\end{array}$ & $\begin{array}{l}-3.647 \\
(5.299)\end{array}$ \\
\hline External Finance/Assets 2007 & $\begin{array}{c}-11.50 * * \\
(4.687)\end{array}$ & $\begin{array}{c}-9.501 * * \\
(4.598)\end{array}$ & $\begin{array}{c}-14.89 * * * \\
(5.055)\end{array}$ & $\begin{array}{c}-11.33 * * \\
(4.940)\end{array}$ \\
\hline Retained Earnings/Assets 2007 & $\begin{array}{l}-2.904 \\
(2.129)\end{array}$ & $\begin{array}{l}-0.105 \\
(2.052)\end{array}$ & $\begin{array}{l}-5.619 * * \\
(2.286)\end{array}$ & $\begin{array}{l}-1.414 \\
(2.192)\end{array}$ \\
\hline Acc. Payable/CGS 2007 & $\begin{array}{c}0.0195 \\
(0.0144)\end{array}$ & $\begin{array}{l}0.0247^{*} \\
(0.0142)\end{array}$ & $\begin{array}{c}0.0202 \\
(0.0159)\end{array}$ & $\begin{array}{c}0.0241 \\
(0.0157)\end{array}$ \\
\hline Exports/Sales $_{2007}$ & $\begin{array}{l}-5.979 * * \\
(2.911)\end{array}$ & $\begin{array}{l}-5.382 * \\
(2.888)\end{array}$ & $\begin{array}{l}-8.091 * * \\
(3.413)\end{array}$ & $\begin{array}{l}-7.065^{* *} \\
(3.379)\end{array}$ \\
\hline Demand Index & & & $\begin{array}{l}1.918 * * \\
(0.924)\end{array}$ & $\begin{array}{l}1.665^{*} \\
(0.915)\end{array}$ \\
\hline Constant & $\begin{array}{c}-40.15 * * * \\
(9.858)\end{array}$ & $\begin{array}{c}-39.50 * * * \\
(9.689)\end{array}$ & $\begin{array}{c}-31.93 * * * \\
(11.36)\end{array}$ & $\begin{array}{c}-30.84 * * * \\
(11.16)\end{array}$ \\
\hline $\begin{array}{l}\text { Observations } \\
\text { R-squared }\end{array}$ & $\begin{array}{l}3,818 \\
0.109\end{array}$ & $\begin{array}{l}3,796 \\
0.113\end{array}$ & $\begin{array}{l}3,195 \\
0.106\end{array}$ & $\begin{array}{l}3,175 \\
0.110\end{array}$ \\
\hline
\end{tabular}

Standard errors in parentheses $* * * \mathrm{p}<0.01,{ }^{* *} \mathrm{p}<0.05,{ }^{*} \mathrm{p}<0.1$

Notes: We construct the demand index for firm $i$ in sector $s$, country $c$ as:

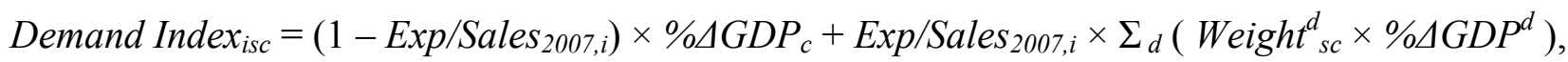
where:

(1) Exp/Sales $2007, i$ is the exports-to-sales ratio of firm $i$ in 2007. It is equal to the exports-to-sales ratio for firms that report either zero or positive exports for 2007, and is assumed to be zero for firms that report positive sales but no exports for 2007;

(2) $\% \triangle G D P_{c}$ is the growth of real GDP for country of origin $c$ between $2008: \mathrm{Q} 3$ and $2009: \mathrm{Q} 1$, as a proxy for domestic demand;

(3) Weight ${ }_{s c}^{d}$ is the share of destination $d$ in the exports of sector $s$ from country $c$; for Taiwan, since Comtrade does not provide trade data, we use Malaysia's sector-specific export shares by destination; (4) $\% \triangle G D P^{d}$ is the growth of real GDP for the destination country $d$ between 2008:Q3 and 2009:Q1, as a proxy for external demand.

The sample includes firms from China, India, Indonesia, Malaysia, Taiwan and Thailand. We rank firms into three categories by the size of their total assets measured in 2007. We use dummy variables to control for firm size, industry and country effects, but do not report their coefficient estimates. 
Table 2. Determinants of Firm Performance (Sales) with Substitution Quadrants:

\section{Baseline Results}

Dependent variable: \% Change in Sales, 2008:Q3-2009:Q1

\begin{tabular}{|c|c|c|c|c|}
\hline VARIABLES & (1) & (2) & (3) & (4) \\
\hline Working Capital/Assets 2007 & $\begin{array}{l}6.690^{*} \\
(3.482)\end{array}$ & & $\begin{array}{c}13.26 * * * \\
(3.773)\end{array}$ & \\
\hline Quick ratio 2007 & & $\begin{array}{c}0.941 * * \\
(0.458)\end{array}$ & & $\begin{array}{c}1.334^{* * *} \\
(0.496)\end{array}$ \\
\hline Short-term debt/Assets 2007 & $\begin{array}{c}-13.26^{* *} \\
(5.653)\end{array}$ & $\begin{array}{c}-14.56^{* * * *} \\
(5.253)\end{array}$ & $\begin{array}{l}-7.913 \\
(6.103)\end{array}$ & $\begin{array}{c}-13.14 * * \\
(5.650)\end{array}$ \\
\hline External Finance/Assets 2007 & $\begin{array}{l}-6.785 \\
(4.872)\end{array}$ & $\begin{array}{l}-5.580 \\
(4.810)\end{array}$ & $\begin{array}{l}-8.809^{*} \\
(5.190)\end{array}$ & $\begin{array}{l}-6.253 \\
(5.112)\end{array}$ \\
\hline Retained Earnings/Assets 2007 & $\begin{array}{l}-0.224 \\
(2.415)\end{array}$ & $\begin{array}{c}0.652 \\
(2.319)\end{array}$ & $\begin{array}{l}-2.354 \\
(2.544)\end{array}$ & $\begin{array}{l}-0.343 \\
(2.446)\end{array}$ \\
\hline Acc. Payable/CGS 2007 & $\begin{array}{l}0.0270^{*} \\
(0.0152)\end{array}$ & $\begin{array}{l}0.0282^{*} \\
(0.0153)\end{array}$ & $\begin{array}{c}0.0265 \\
(0.0167)\end{array}$ & $\begin{array}{c}0.0251 \\
(0.0168)\end{array}$ \\
\hline Exports/Sales 2007 & $\begin{array}{l}-3.521 \\
(2.986)\end{array}$ & $\begin{array}{l}-3.257 \\
(2.991)\end{array}$ & $\begin{array}{l}-5.871 \\
(3.702)\end{array}$ & $\begin{array}{l}-5.499 \\
(3.708)\end{array}$ \\
\hline Demand Index & & & $\begin{array}{l}1.982^{*} \\
(1.054)\end{array}$ & $\begin{array}{l}1.860^{*} \\
(1.055)\end{array}$ \\
\hline I_Quad1 & $\begin{array}{c}6.642 * * * \\
(1.721)\end{array}$ & $\begin{array}{c}6.351 * * * \\
(1.726)\end{array}$ & $\begin{array}{c}7.445^{* * * *} \\
(1.858)\end{array}$ & $\begin{array}{c}6.959^{* * *} \\
(1.866)\end{array}$ \\
\hline I_Quad2 & $\begin{array}{c}8.839^{* * * *} \\
(1.765)\end{array}$ & $\begin{array}{c}8.862 * * * \\
(1.766)\end{array}$ & $\begin{array}{c}10.38^{* * *} \\
(1.898)\end{array}$ & $\begin{array}{c}10.15^{* * *} \\
(1.900)\end{array}$ \\
\hline I_Quad3 & $\begin{array}{l}-0.690 \\
(1.515)\end{array}$ & $\begin{array}{l}-0.697 \\
(1.515)\end{array}$ & $\begin{array}{c}0.161 \\
(1.595)\end{array}$ & $\begin{array}{l}-0.0723 \\
(1.593)\end{array}$ \\
\hline Constant & $\begin{array}{c}-38.56^{* * * *} \\
(9.802)\end{array}$ & $\begin{array}{c}-37.54 * * * \\
(9.714)\end{array}$ & $\begin{array}{c}-30.08^{* *} \\
(11.72)\end{array}$ & $\begin{array}{c}-27.45^{* *} \\
(11.68)\end{array}$ \\
\hline Observations & 3,291 & 3,280 & 2,762 & 2,753 \\
\hline R-squared & 0.135 & 0.135 & 0.132 & 0.129 \\
\hline
\end{tabular}

Standard errors in parentheses

$* * * \mathrm{p}<0.01, * * \mathrm{p}<0.05, * \mathrm{p}<0.1$

Notes: For Demand Index, see the notes to Table 1.

The sample includes firms from China, India, Indonesia, Malaysia, Taiwan and Thailand. We rank firms into three categories by the size of their total assets measured in 2007. We use dummy variables to control for firm size, industry and country effects, but do not report their coefficient estimates. 
Table 3. Determinants of Trade Credit:

Baseline Results

Dependent variable: Change in the Acc. Payable/Cost of Goods Sold Ratio, 2008:Q3-2009:Q1

\begin{tabular}{lcccc}
\hline & $(1)$ & $(2)$ & $(3)$ & $(4)$ \\
VARIABLES & & & & \\
\hline & & & -2.656 & \\
Working Capital/Assets 2007 & -2.857 & & $(3.783)$ & \\
& $(3.443)$ & -0.191 & & -0.356 \\
Quick ratio 2007 & & $(0.387)$ & & $(0.434)$ \\
& & $17.32^{* * *}$ & $16.48^{* * *}$ & $17.12^{* * *}$ \\
Short-term debt/Assets 2007 & $15.65^{* * *}$ & $(5.286)$ & $(6.290)$ & $(5.827)$ \\
& $(5.699)$ & 8.093 & $14.62^{* *}$ & $14.77^{* *}$ \\
External Finance/Assets 2007 & 8.428 & $(5.713)$ & $(6.428)$ & $(6.423)$ \\
& $(5.730)$ & 0.603 & 1.870 & 1.461 \\
Retained Earnings/Assets 2007 & 1.180 & $(2.037)$ & $(2.278)$ & $(2.214)$ \\
& $(2.104)$ & $-4.954^{*}$ & $-5.068^{*}$ & $-4.954^{*}$ \\
Exports/Sales 2007 & $-5.025^{* *}$ & $(2.531)$ & $(2.813)$ & $(2.827)$ \\
& $(2.516)$ & & -0.174 & -0.189 \\
Demand Index & & & $(0.709)$ & $(0.711)$ \\
& & 9.941 & 10.21 & 9.897 \\
Constant & 10.59 & $(11.04)$ & $(11.70)$ & $(11.69)$ \\
& $(11.02)$ & & \\
Observations & 1,573 & 1,562 & 1,304 & 1,294 \\
R-squared & 0.065 & 0.066 & 0.080 & 0.082 \\
\hline
\end{tabular}

$$
\begin{gathered}
\text { Standard errors in parentheses } \\
* * * \mathrm{p}<0.01,{ }^{* *} \mathrm{p}<0.05, * \mathrm{p}<0.1
\end{gathered}
$$

Notes: For Demand Index, see the notes to Table 1.

The sample includes firms from China, India, Indonesia, Malaysia, Taiwan and Thailand. We rank firms into three categories by the size of their total assets. We use dummy variables to control for firm size, industry and country effects, but do not report their coefficient estimates. 
Table 4. Logit Model of Exporter Status as a Function of Firm Size

\begin{tabular}{|c|c|c|c|c|}
\hline Dependent variable: & VARIABLES & (1) & & \\
\hline \multirow[t]{3}{*}{ I_exporter_2007 } & $\ln ($ Tot. Assets 2007$)$ & $\begin{array}{l}0.316^{* * * *} \\
(0.0591)\end{array}$ & $\begin{array}{l}\text { Log likelihood } \\
\text { chi2(26) }\end{array}$ & $\begin{array}{r}-545.1 \\
245.9\end{array}$ \\
\hline & Constant & $\begin{array}{c}14.07 \\
(891.5)\end{array}$ & Prob $>$ chi 2 & 0 \\
\hline & $\begin{array}{l}\text { Observations } \\
\text { Pseudo R-squared }\end{array}$ & $\begin{array}{l}1,243 \\
0.184\end{array}$ & & \\
\hline
\end{tabular}

Note: We use dummy variables to control for industry and country effects, but do not report their coefficient estimates.

Table 5. Determinants of Firm Performance (Sales) with Substitution Quadrants: Robustness to the Exports-to-Sales Ratio Constructed from Logit Model

Dependent variable: \% Change in Sales, 2008:Q3-2009:Q1

\begin{tabular}{|c|c|c|c|c|}
\hline VARIABLES & (1) & $(2)$ & (3) & (4) \\
\hline Working Capital/Assets 2007 & $\begin{array}{l}7.992 * * \\
(3.327)\end{array}$ & & $\begin{array}{c}14.75 * * * \\
(3.649)\end{array}$ & \\
\hline Quick ratio $_{2007}$ & & $\begin{array}{c}1.265^{* * *} * \\
(0.402)\end{array}$ & & $\begin{array}{c}1.809^{* * * *} \\
(0.437)\end{array}$ \\
\hline Short-term debt/Assets 2007 & $\begin{array}{c}-6.964 \\
(5.461)\end{array}$ & $\begin{array}{l}-6.208 \\
(4.991)\end{array}$ & $\begin{array}{l}0.0381 \\
(5.951)\end{array}$ & $\begin{array}{c}-2.399 \\
(5.395)\end{array}$ \\
\hline External Finance/Assets 2007 & $\begin{array}{c}-11.08 * * \\
(4.801)\end{array}$ & $\begin{array}{c}-9.040 * \\
(4.706)\end{array}$ & $\begin{array}{c}-13.95 * * * \\
(5.162)\end{array}$ & $\begin{array}{c}-10.48 * * \\
(5.039)\end{array}$ \\
\hline Retained Earnings/Assets 2007 & $\begin{array}{l}-2.881 \\
(2.157)\end{array}$ & $\begin{array}{r}-0.0821 \\
(2.076)\end{array}$ & $\begin{array}{c}-5.196^{* *} \\
(2.306)\end{array}$ & $\begin{array}{l}-1.084 \\
(2.208)\end{array}$ \\
\hline Acc. Payable/CGS 2007 & $\begin{array}{c}0.0184 \\
(0.0147)\end{array}$ & $\begin{array}{c}0.0235 \\
(0.0146)\end{array}$ & $\begin{array}{c}0.0211 \\
(0.0162)\end{array}$ & $\begin{array}{c}0.0251 \\
(0.0160)\end{array}$ \\
\hline Exports/Sales $_{2007}$, logit & $\begin{array}{c}-24.65^{* *} \\
(10.03)\end{array}$ & $\begin{array}{c}-24.03 * * \\
(9.966)\end{array}$ & $\begin{array}{c}-31.43 * * \\
(12.88)\end{array}$ & $\begin{array}{c}-31.22 * * \\
(12.76)\end{array}$ \\
\hline Demand Index, logit & & & $\begin{array}{l}-0.129 \\
(0.839)\end{array}$ & $\begin{array}{c}-0.0754 \\
(0.830)\end{array}$ \\
\hline Constant & $\begin{array}{l}-20.35 \\
(12.97)\end{array}$ & $\begin{array}{c}-20.12 \\
(12.78)\end{array}$ & $\begin{array}{l}-18.53 \\
(14.25)\end{array}$ & $\begin{array}{l}-15.91 \\
(14.00)\end{array}$ \\
\hline Observations & 3,655 & 3,633 & 3,086 & 3,066 \\
\hline R-squared & 0.107 & 0.111 & 0.103 & 0.107 \\
\hline
\end{tabular}

Notes: Exports/Sales ${ }_{2007}$, logit is the probability that firms were exporters in 2007 . We first estimate a logit model of the relationship between exports and total assets for the sub-sample of firms that report exports in 2007 (Table 4). We then use the logit estimates to compute the export probabilities as a function of total assets for the entire sample, including for firms that do not report exports for 2007, which is the explanatory variable in Table 5.

Demand Index, logit is constructed as explained in the notes to Table 1, except for that we now use Exports/Sales 2007 , logit to compute the weights for domestic vs. international demand.

The sample includes firms from China, India, Indonesia, Malaysia, Taiwan and Thailand. We rank firms into three categories by the size of their total assets. We use dummy variables to control for firm size, industry and country effects, but do not report their coefficient estimates. 


\section{Table 6. Determinants of Firm Performance (Sales) with Substitution Quadrants: Robustness to the Exports-to-Sales Ratio Constructed from Logit Model}

Dependent variable: \% Change in Sales, 2008:Q3-2009:Q1

\begin{tabular}{|c|c|c|c|c|}
\hline VARIABLES & $(1)$ & $(2)$ & (3) & $(4)$ \\
\hline Working Capital/Assets 2007 & $\begin{array}{l}6.792^{*} \\
(3.573)\end{array}$ & & $\begin{array}{c}12.97 * * * \\
(3.858)\end{array}$ & \\
\hline Quick ratio 2007 & & $\begin{array}{c}0.940 * * \\
(0.467)\end{array}$ & & $\begin{array}{c}1.357 * * * \\
(0.506)\end{array}$ \\
\hline Short-term debt/Assets 2007 & $\begin{array}{c}-13.03 * * \\
(5.825)\end{array}$ & $\begin{array}{c}-14.52 * * * \\
(5.382)\end{array}$ & $\begin{array}{l}-7.290 \\
(6.270)\end{array}$ & $\begin{array}{c}-12.40 * * \\
(5.766)\end{array}$ \\
\hline External Finance/Assets 2007 & $\begin{array}{l}-6.535 \\
(5.005)\end{array}$ & $\begin{array}{l}-5.248 \\
(4.940)\end{array}$ & $\begin{array}{l}-8.369 \\
(5.305)\end{array}$ & $\begin{array}{l}-5.914 \\
(5.225)\end{array}$ \\
\hline Retained Earnings/Assets 2007 & $\begin{array}{l}-0.208 \\
(2.456)\end{array}$ & $\begin{array}{c}0.669 \\
(2.356)\end{array}$ & $\begin{array}{l}-2.006 \\
(2.567)\end{array}$ & $\begin{array}{l}-0.123 \\
(2.466)\end{array}$ \\
\hline Acc. Payable/CGS 2007 & $\begin{array}{c}0.0237 \\
(0.0157)\end{array}$ & $\begin{array}{c}0.0247 \\
(0.0157)\end{array}$ & $\begin{array}{c}0.0257 \\
(0.0171)\end{array}$ & $\begin{array}{c}0.0243 \\
(0.0171)\end{array}$ \\
\hline Exports/Sales 2007, logit & $\begin{array}{c}-26.58 * * \\
(10.45)\end{array}$ & $\begin{array}{c}-25.77 * * \\
(10.49)\end{array}$ & $\begin{array}{l}-23.56^{*} \\
(13.42)\end{array}$ & $\begin{array}{l}-22.93 * \\
(13.46)\end{array}$ \\
\hline Demand Index, logit & & & $\begin{array}{c}0.634 \\
(0.885)\end{array}$ & $\begin{array}{c}0.574 \\
(0.887)\end{array}$ \\
\hline I_Quad1 & $\begin{array}{c}6.539 * * * \\
(1.757)\end{array}$ & $\begin{array}{c}6.255 * * * \\
(1.764)\end{array}$ & $\begin{array}{c}7.509 * * * \\
(1.886)\end{array}$ & $\begin{array}{c}7.015 * * * \\
(1.895)\end{array}$ \\
\hline I_Quad2 & $\begin{array}{c}9.281^{* * * *} \\
(1.823)\end{array}$ & $\begin{array}{c}9.321 * * * \\
(1.825)\end{array}$ & $\begin{array}{c}10.65 * * * \\
(1.952)\end{array}$ & $\begin{array}{c}10.45^{* * * *} \\
(1.953)\end{array}$ \\
\hline I_Quad3 & $\begin{array}{l}-0.334 \\
(1.568)\end{array}$ & $\begin{array}{l}-0.324 \\
(1.568)\end{array}$ & $\begin{array}{c}0.271 \\
(1.639)\end{array}$ & $\begin{array}{l}0.0958 \\
(1.638)\end{array}$ \\
\hline Constant & $\begin{array}{l}-16.77 \\
(13.19)\end{array}$ & $\begin{array}{l}-16.31 \\
(13.10)\end{array}$ & $\begin{array}{l}-21.01 \\
(14.45)\end{array}$ & $\begin{array}{l}-18.48 \\
(14.33)\end{array}$ \\
\hline $\begin{array}{l}\text { Observations } \\
\text { R-squared }\end{array}$ & $\begin{array}{l}3,134 \\
0.133\end{array}$ & $\begin{array}{l}3,123 \\
0.133\end{array}$ & $\begin{array}{l}2,658 \\
0.128\end{array}$ & $\begin{array}{l}2,649 \\
0.126\end{array}$ \\
\hline
\end{tabular}

$$
\begin{aligned}
& \text { Standard errors in parentheses } \\
& * * * \mathrm{p}<0.01, * * \mathrm{p}<0.05, * \mathrm{p}<0.1
\end{aligned}
$$

Notes: For Exports/Sales 2007 , logit and Demand Index, logit, see the notes to Table 5.

The sample includes firms from China, India, Indonesia, Malaysia, Taiwan and Thailand. We rank firms into three categories by the size of their total assets measured in 2007. We use dummy variables to control for firm size, industry and country effects, but do not report their coefficient estimates. 


\section{Table 7. Determinants of Firm Performance (Sales):}

\section{Robustness to the Exports-to-Sales Ratio Constructed from 2-digit Sector Averages}

Dependent variable: \% Change in Sales, 2008:Q3-2009:Q1

\begin{tabular}{|c|c|c|c|c|}
\hline VARIABLES & (1) & (2) & (3) & (4) \\
\hline Working Capital/Assets 2007 & $\begin{array}{c}10.16^{* * *} \\
(3.631)\end{array}$ & & $\begin{array}{c}11.84 * * * \\
(3.797)\end{array}$ & \\
\hline Quick ratio 2007 & & $\begin{array}{c}1.633 * * * \\
(0.441)\end{array}$ & & $\begin{array}{c}1.841 * * * \\
(0.457)\end{array}$ \\
\hline Short-term debt/Assets 2007 & $\begin{array}{l}-4.752 \\
(5.810)\end{array}$ & $\begin{array}{l}-5.555 \\
(5.400)\end{array}$ & $\begin{array}{l}-2.346 \\
(6.124)\end{array}$ & $\begin{array}{l}-3.555 \\
(5.670)\end{array}$ \\
\hline External Finance/Assets 2007 & $\begin{array}{c}-13.24 * * \\
(5.207)\end{array}$ & $\begin{array}{c}-11.96^{* *} \\
(5.135)\end{array}$ & $\begin{array}{c}-12.87 * * \\
(5.368)\end{array}$ & $\begin{array}{c}-11.30 * * \\
(5.291)\end{array}$ \\
\hline Retained Earnings/Assets 2007 & $\begin{array}{l}-2.414 \\
(2.369)\end{array}$ & $\begin{array}{l}-1.190 \\
(2.269)\end{array}$ & $\begin{array}{l}-3.221 \\
(2.420)\end{array}$ & $\begin{array}{l}-1.794 \\
(2.318)\end{array}$ \\
\hline Acc. Payable/CGS 2007 & $\begin{array}{c}0.0118 \\
(0.0158)\end{array}$ & $\begin{array}{c}0.0141 \\
(0.0158)\end{array}$ & $\begin{array}{l}0.00828 \\
(0.0166)\end{array}$ & $\begin{array}{c}0.0109 \\
(0.0166)\end{array}$ \\
\hline Exports/Sales 2007 , 2-digit sector & $\begin{array}{l}-8.174 * \\
(4.219)\end{array}$ & $\begin{array}{c}-7.794 * \\
(4.239)\end{array}$ & $\begin{array}{c}-11.74 * * \\
(4.671)\end{array}$ & $\begin{array}{c}-11.35^{* *} \\
(4.692)\end{array}$ \\
\hline Demand Index, 2-digit sector & & & $\begin{array}{c}2.973 * * * \\
(0.987)\end{array}$ & $\begin{array}{c}2.964^{* * * *} \\
(0.988)\end{array}$ \\
\hline Constant & $\begin{array}{l}-44.73^{*} \\
(24.91)\end{array}$ & $\begin{array}{l}-43.77^{*} \\
(24.88)\end{array}$ & $\begin{array}{l}-30.35 \\
(25.29)\end{array}$ & $\begin{array}{l}-29.19 \\
(25.26)\end{array}$ \\
\hline Observations & 3,119 & 3,101 & 2,825 & 2,807 \\
\hline R-squared & 0.100 & 0.101 & 0.107 & 0.108 \\
\hline
\end{tabular}

Notes: The Exports/Sales 2007 , 2-digit sector variable is equal to the firm-specific ratio for firms that report either zero or positive exports for 2007; it is equal to the sector average ratio for firms that report sales but not exports for 2007, as described in the text.

The Demand Index, 2-digit sector is constructed as explained in the notes to Table 1, except for that we now use Exports/Sales 2007, 2-digit sector to compute the weights for domestic vs. international demand.

The sample includes firms from China, India, Indonesia, Malaysia, Taiwan and Thailand. We rank firms into three categories by the size of their total assets measured in 2007. We use dummy variables to control for firm size, industry and country effects, but do not report their coefficient estimates. 
Table 8. Determinants of Firm Performance (Sales) with Substitution Quadrants:

Robustness to the Exports-to-Sales Ratio Constructed from 2-digit Sector Averages

Dependent variable: \% Change in Sales, 2008:Q3-2009:Q1

\begin{tabular}{|c|c|c|c|c|}
\hline VARIABLES & (1) & (2) & (3) & (4) \\
\hline Working Capital/Assets 2007 & $\begin{array}{c}9.937 * * * \\
(3.829)\end{array}$ & & $\begin{array}{c}13.02 * * * \\
(3.968)\end{array}$ & \\
\hline Quick ratio 2007 & & $\begin{array}{c}1.009 * * \\
(0.503)\end{array}$ & & $\begin{array}{c}1.267 * * \\
(0.521)\end{array}$ \\
\hline Short-term debt/Assets 2007 & $\begin{array}{c}-12.61 * * \\
(6.141)\end{array}$ & $\begin{array}{c}-16.22 * * * \\
(5.738)\end{array}$ & $\begin{array}{l}-8.912 \\
(6.434)\end{array}$ & $\begin{array}{c}-14.00 * * \\
(5.998)\end{array}$ \\
\hline External Finance/Assets 2007 & $\begin{array}{l}-8.464 \\
(5.404)\end{array}$ & $\begin{array}{l}-6.411 \\
(5.318)\end{array}$ & $\begin{array}{l}-8.230 \\
(5.521)\end{array}$ & $\begin{array}{l}-5.555 \\
(5.433)\end{array}$ \\
\hline Retained Earnings/Assets 2007 & $\begin{array}{l}-1.362 \\
(2.640)\end{array}$ & $\begin{array}{c}0.211 \\
(2.532)\end{array}$ & $\begin{array}{l}-2.313 \\
(2.683)\end{array}$ & $\begin{array}{l}-0.278 \\
(2.579)\end{array}$ \\
\hline Acc. Payable/CGS 2007 & $\begin{array}{c}0.0172 \\
(0.0167)\end{array}$ & $\begin{array}{c}0.0163 \\
(0.0167)\end{array}$ & $\begin{array}{c}0.0141 \\
(0.0175)\end{array}$ & $\begin{array}{c}0.0123 \\
(0.0175)\end{array}$ \\
\hline Exports/Sales 2007 , 2-digit sector & $\begin{array}{c}-8.821 * * \\
(4.390)\end{array}$ & $\begin{array}{l}-8.316^{*} \\
(4.412)\end{array}$ & $\begin{array}{c}-12.78 * * * \\
(4.896)\end{array}$ & $\begin{array}{c}-12.10 * * \\
(4.922)\end{array}$ \\
\hline Demand Index, 2-digit sector & & & $\begin{array}{c}3.745 * * * \\
(1.056)\end{array}$ & $\begin{array}{c}3.700 * * * \\
(1.059)\end{array}$ \\
\hline I_Quad1 & $\begin{array}{c}7.495 * * * \\
(1.898)\end{array}$ & $\begin{array}{c}7.102 * * * \\
(1.904)\end{array}$ & $\begin{array}{c}7.839 * * * \\
(1.980)\end{array}$ & $\begin{array}{c}7.292 * * * \\
(1.988)\end{array}$ \\
\hline I_Quad2 & $\begin{array}{c}9.782 * * * \\
(1.929)\end{array}$ & $\begin{array}{c}9.695 * * * \\
(1.929)\end{array}$ & $\begin{array}{c}9.702 * * * \\
(2.008)\end{array}$ & $\begin{array}{c}9.449 * * * \\
(2.009)\end{array}$ \\
\hline I_Quad3 & $\begin{array}{l}-0.286 \\
(1.629)\end{array}$ & $\begin{array}{l}-0.407 \\
(1.628)\end{array}$ & $\begin{array}{l}-0.397 \\
(1.680)\end{array}$ & $\begin{array}{l}-0.648 \\
(1.678)\end{array}$ \\
\hline Constant & $\begin{array}{l}-45.65^{*} \\
(23.81)\end{array}$ & $\begin{array}{l}-43.11 * \\
(23.78)\end{array}$ & $\begin{array}{l}-28.00 \\
(24.18)\end{array}$ & $\begin{array}{l}-24.74 \\
(24.18)\end{array}$ \\
\hline $\begin{array}{l}\text { Observations } \\
\text { R-squared }\end{array}$ & $\begin{array}{l}2,713 \\
0.124\end{array}$ & $\begin{array}{l}2,704 \\
0.122\end{array}$ & $\begin{array}{l}2,456 \\
0.133\end{array}$ & $\begin{array}{l}2,447 \\
0.131\end{array}$ \\
\hline
\end{tabular}

Notes: For Exports/Sales 2007, 2-digit sector and Demand Index, 2-digit sector, see the notes to Table 7.

The sample includes firms from China, India, Indonesia, Malaysia, Taiwan and Thailand. We rank firms into three categories by the size of their total assets measured in 2007 . We use dummy variables to control for firm size, industry and country effects, but do not report their coefficient estimates. 
Table 9. Determinants of Trade Credit:

Robustness to the Exports-to-Sales Ratio Constructed from 2-digit Sector Averages

Dependent variable: Change in the Acc. Payable/Cost of Goods Sold Ratio, 2008:Q3-2009:Q1

\begin{tabular}{lcccc}
\hline & $(1)$ & $(2)$ & $(3)$ & $(4)$ \\
VARIABLES & & & & \\
\hline & & & -1.670 & \\
Working Capital/Assets 2007 & -0.204 & & $(4.031)$ & -0.314 \\
Quick ratio 2007 & $(3.848)$ & & & $(0.472)$ \\
& & -0.293 & & \\
Short-term debt/Assets 2007 & $19.77^{* * *}$ & $18.52^{* * *}$ & $18.45^{* * *}$ & $18.37^{* * *}$ \\
& $(6.312)$ & $(5.935)$ & $(6.708)$ & $(6.279)$ \\
External Finance/Assets 2007 & $11.97^{*}$ & $12.66^{*}$ & $12.30^{*}$ & $12.46^{*}$ \\
& $(6.457)$ & $(6.457)$ & $(6.779)$ & $(6.774)$ \\
Retained Earnings/Assets 2007 & 0.934 & 1.091 & 0.568 & 0.471 \\
& $(2.330)$ & $(2.266)$ & $(2.382)$ & $(2.314)$ \\
Exports/Sales $2007,2-$ digit sector & $-6.508^{*}$ & $-6.393 *$ & $-9.014 * *$ & $-8.830^{* *}$ \\
Demand Index, 2-digit sector & $(3.464)$ & $(3.498)$ & $(3.712)$ & $(3.747)$ \\
& & & $2.007^{* *}$ & $2.018^{* *}$ \\
Constant & & & $(0.845)$ & $(0.848)$ \\
& 5.891 & 6.319 & 18.03 & 18.02 \\
Observations & $(17.25)$ & $(17.26)$ & $(17.74)$ & $(17.76)$ \\
R-squared & & & & 1,126 \\
\hline
\end{tabular}

$$
\begin{aligned}
& \text { Standard errors in parentheses } \\
& * * * \mathrm{p}<0.01, * * \mathrm{p}<0.05, * \mathrm{p}<0.1
\end{aligned}
$$

Notes: For Exports/Sales 2007, 2-digit sector and Demand Index, 2-digit sector, see the notes to Table 7.

The sample includes firms from China, India, Indonesia, Malaysia, Taiwan and Thailand. We rank firms into three categories by the size of their total assets. We use dummy variables to control for firm size, industry and country effects, but do not report their coefficient estimates. 
Table 10. Determinants of Firm Performance (Sales): Robustness to Inventories

Dependent variable: \% Change in Sales, 2008:Q3-2009:Q1

\begin{tabular}{|c|c|c|c|c|}
\hline VARIABLES & (1) & (2) & (3) & (4) \\
\hline Quick ratio $_{2007}$ & $\begin{array}{c}1.051 * * \\
(0.462)\end{array}$ & $\begin{array}{c}1.338 * * * \\
(0.501)\end{array}$ & $\begin{array}{c}1.545^{* * *} * \\
(0.498)\end{array}$ & $\begin{array}{c}1.973 * * * \\
(0.539)\end{array}$ \\
\hline Short-term debt/Assets 2007 & $\begin{array}{c}-16.76 * * * \\
(5.295)\end{array}$ & $\begin{array}{c}-19.39 * * * \\
(6.141)\end{array}$ & $\begin{array}{c}-15.02 * * * \\
(5.685)\end{array}$ & $\begin{array}{c}-19.45 * * * \\
(6.657)\end{array}$ \\
\hline External Finance/Assets 2007 & $\begin{array}{l}-6.995 \\
(4.800)\end{array}$ & $\begin{array}{c}-19.30 * * * \\
(5.707)\end{array}$ & $\begin{array}{l}-8.531 * \\
(5.087)\end{array}$ & $\begin{array}{c}-20.21 * * * \\
(6.121)\end{array}$ \\
\hline Retained Earnings/Assets 2007 & $\begin{array}{c}0.547 \\
(2.310)\end{array}$ & $\begin{array}{c}1.580 \\
(2.726)\end{array}$ & $\begin{array}{l}-0.591 \\
(2.427)\end{array}$ & $\begin{array}{c}1.566 \\
(2.865)\end{array}$ \\
\hline Acc. Payable/CGS 2007 & $\begin{array}{c}0.0192 \\
(0.0154)\end{array}$ & $\begin{array}{c}0.0102 \\
(0.0179)\end{array}$ & $\begin{array}{c}0.0123 \\
(0.0169)\end{array}$ & $\begin{array}{l}-0.0105 \\
(0.0196)\end{array}$ \\
\hline Exports/Sales 2007 & $\begin{array}{l}-2.960 \\
(2.978)\end{array}$ & $\begin{array}{l}-2.917 \\
(2.972)\end{array}$ & $\begin{array}{l}-5.099 \\
(3.676)\end{array}$ & $\begin{array}{l}-5.179 \\
(3.664)\end{array}$ \\
\hline Demand Index & & & $\begin{array}{l}1.929^{*} \\
(1.046)\end{array}$ & $\begin{array}{l}1.979 * \\
(1.042)\end{array}$ \\
\hline I_Quad1 & $\begin{array}{c}6.484 * * * \\
(1.721)\end{array}$ & $\begin{array}{c}6.615^{* * *} \\
(1.719)\end{array}$ & $\begin{array}{c}7.216^{* * *} \\
(1.853)\end{array}$ & $\begin{array}{c}7.471 * * * \\
(1.850)\end{array}$ \\
\hline I_Quad2 & $\begin{array}{c}8.738 * * * \\
(1.763)\end{array}$ & $\begin{array}{c}8.594 * * * \\
(1.759)\end{array}$ & $\begin{array}{c}9.995 * * * \\
(1.891)\end{array}$ & $\begin{array}{c}9.691 * * * \\
(1.884)\end{array}$ \\
\hline I_Quad3 & $\begin{array}{l}-0.588 \\
(1.511)\end{array}$ & $\begin{array}{l}-0.636 \\
(1.507)\end{array}$ & $\begin{array}{l}0.0829 \\
(1.583)\end{array}$ & $\begin{array}{l}0.0313 \\
(1.577)\end{array}$ \\
\hline Inventories/Sales 2007 & $\begin{array}{c}6.504 * * * \\
(1.954)\end{array}$ & & $\begin{array}{c}9.002 * * * \\
(2.102)\end{array}$ & \\
\hline Inv/Sales $2007 \times$ Quick ratio 2007 & & $\begin{array}{l}-3.041^{*} \\
(1.721)\end{array}$ & & $\begin{array}{c}-4.647 * * * \\
(1.783)\end{array}$ \\
\hline Inv/Sales $2007 \times$ Short-term debt/Assets 2007 & & $\begin{array}{c}9.647 \\
(11.11)\end{array}$ & & $\begin{array}{c}13.68 \\
(11.95)\end{array}$ \\
\hline${\text { Inv } / \text { Sales }_{2007} \times \text { Ext. Finance/Assets }}_{2007}$ & & $\begin{array}{c}53.40 * * * \\
(12.91)\end{array}$ & & $\begin{array}{c}49.26 * * * \\
(13.20)\end{array}$ \\
\hline Inv/Sales $2007 \times$ Ret. Earnings/Assets 2007 & & $\begin{array}{l}-3.924 \\
(6.797)\end{array}$ & & $\begin{array}{l}-8.935 \\
(6.844)\end{array}$ \\
\hline Inv/Sales $2007 \times$ Acc. Payable/CGS 2007 & & $\begin{array}{c}0.0270 \\
(0.0259)\end{array}$ & & $\begin{array}{c}0.0647 * * \\
(0.0280)\end{array}$ \\
\hline Constant & $\begin{array}{c}-38.88 * * * \\
(9.680)\end{array}$ & $\begin{array}{c}-37.09 * * * \\
(9.642)\end{array}$ & $\begin{array}{c}-29.19 * * \\
(11.59)\end{array}$ & $\begin{array}{c}-25.94 * * \\
(11.54)\end{array}$ \\
\hline $\begin{array}{l}\text { Observations } \\
\text { R-squared }\end{array}$ & $\begin{array}{l}3,258 \\
0.139\end{array}$ & $\begin{array}{l}3,258 \\
0.145\end{array}$ & $\begin{array}{l}2,736 \\
0.137\end{array}$ & $\begin{array}{l}2,736 \\
0.145\end{array}$ \\
\hline
\end{tabular}

Standard errors in parentheses

$* * * \mathrm{p}<0.01, * * \mathrm{p}<0.05, * \mathrm{p}<0.1$

Notes: Columns (1) and (3) add the inventory-to-sales ratio for 2007 as an explanatory variable to the baseline specifications with the Quick Ratio in Table 2. Columns (2) and (4) add interactions of the inventory-to-sales ratio with each of the financial variables on rows 1-5. As in Table 2, we use dummy variables to control for firm size, industry and country effects, but do not report their coefficient estimates. 
Table 11. Determinants of Firm Performance (Sales):

Robustness to Sample Composition (Number of Firms)

Dependent variable: \% Change in Sales, 2008:Q3-2009:Q1

\begin{tabular}{|c|c|c|c|c|}
\hline VARIABLES & (1) & (2) & (3) & (4) \\
\hline Working Capital/Assets 2007 & $\begin{array}{c}5.312 \\
(5.137)\end{array}$ & & $\begin{array}{c}11.38^{* *} \\
(5.662)\end{array}$ & \\
\hline Quick ratio $_{2007}$ & & $\begin{array}{c}0.583 \\
(0.655)\end{array}$ & & $\begin{array}{c}0.769 \\
(0.765)\end{array}$ \\
\hline Short-term debt/Assets 2007 & $\begin{array}{l}-2.888 \\
(8.570)\end{array}$ & $\begin{array}{l}-4.758 \\
(7.849)\end{array}$ & $\begin{array}{c}2.194 \\
(9.361)\end{array}$ & $\begin{array}{l}-4.380 \\
(8.638)\end{array}$ \\
\hline External Finance/Assets 2007 & $\begin{array}{c}-22.98 * * * \\
(8.394)\end{array}$ & $\begin{array}{c}-22.25 * * * \\
(8.359)\end{array}$ & $\begin{array}{c}-22.49^{* *} \\
(9.341)\end{array}$ & $\begin{array}{c}-20.61 * * \\
(9.308)\end{array}$ \\
\hline Retained Earnings/Assets 2007 & $\begin{array}{c}6.202^{* *} \\
(3.093)\end{array}$ & $\begin{array}{c}6.666^{* *} \\
(3.013)\end{array}$ & $\begin{array}{c}5.005 \\
(3.403)\end{array}$ & $\begin{array}{l}6.145^{*} \\
(3.343)\end{array}$ \\
\hline Acc. Payable/CGS 2007 & $\begin{array}{c}0.0570^{* *} \\
(0.0241)\end{array}$ & $\begin{array}{c}0.0570^{* *} \\
(0.0241)\end{array}$ & $\begin{array}{c}0.0667^{* *} \\
(0.0277)\end{array}$ & $\begin{array}{c}0.0637^{* *} \\
(0.0278)\end{array}$ \\
\hline Exports/Sales 2007 & $\begin{array}{l}-3.731 \\
(3.519)\end{array}$ & $\begin{array}{l}-3.177 \\
(3.528)\end{array}$ & $\begin{array}{l}-7.109^{*} \\
(4.098)\end{array}$ & $\begin{array}{l}-6.424 \\
(4.111)\end{array}$ \\
\hline Demand Index & & & $\begin{array}{l}2.097^{*} \\
(1.081)\end{array}$ & $\begin{array}{l}2.124^{*} \\
(1.084)\end{array}$ \\
\hline I_Quad1 & $\begin{array}{l}5.112^{*} \\
(2.612)\end{array}$ & $\begin{array}{l}4.798^{*} \\
(2.635)\end{array}$ & $\begin{array}{l}4.941^{*} \\
(2.895)\end{array}$ & $\begin{array}{c}4.360 \\
(2.921)\end{array}$ \\
\hline I_Quad2 & $\begin{array}{c}8.196 * * * \\
(2.683)\end{array}$ & $\begin{array}{c}8.392 * * * \\
(2.694)\end{array}$ & $\begin{array}{c}9.379^{* * * *} \\
(2.962)\end{array}$ & $\begin{array}{c}9.492 * * * \\
(2.976)\end{array}$ \\
\hline I_Quad3 & $\begin{array}{c}0.686 \\
(2.168)\end{array}$ & $\begin{array}{c}0.703 \\
(2.170)\end{array}$ & $\begin{array}{c}0.875 \\
(2.338)\end{array}$ & $\begin{array}{c}0.712 \\
(2.340)\end{array}$ \\
\hline Constant & $\begin{array}{c}-51.52 * * * \\
(15.59)\end{array}$ & $\begin{array}{c}-50.66^{* * * *} \\
(15.55)\end{array}$ & $\begin{array}{c}-41.55^{* *} \\
(16.84)\end{array}$ & $\begin{array}{c}-38.42 * * \\
(16.83)\end{array}$ \\
\hline Observations & 1,237 & 1,233 & 1,025 & 1,022 \\
\hline R-squared & 0.174 & 0.174 & 0.173 & 0.171 \\
\hline
\end{tabular}

Notes: We use the baseline specification from Table 2, but only for the sub-sample of firms that report both sales and accounts payable at the quarterly frequency. As in Table 2, we use dummy variables to control for firm size, industry and country effects, but do not report their coefficient estimates. 
Table 12. Determinants of Firm Performance (Sales):

Robustness to Sample Composition (Countries)

Dependent variable: \% Change in Sales, 2008:Q3-2009:Q1

$\begin{array}{llllll}(1) & (2) & (3) & (4) & (5)\end{array}$

VARIABLES

\begin{tabular}{lcccccc} 
& $1.679 * * *$ & $0.983^{* *}$ & $0.970^{* *}$ & 0.327 & $0.937 * *$ & 0.757 \\
Quick ratio 2007 & $(0.527)$ & $(0.452)$ & $(0.464)$ & $(0.530)$ & $(0.459)$ & $(0.615)$ \\
Short-term debt/Assets 2007 & -5.570 & $-13.57^{* * *}$ & $-16.55^{* * *}$ & $-17.26^{* * *}$ & $-14.59^{* * *}$ & $-18.18^{* * *}$ \\
& $(6.832)$ & $(5.189)$ & $(5.462)$ & $(5.696)$ & $(5.262)$ & $(6.684)$ \\
External Finance/Assets 2007 & 1.810 & $-8.063^{*}$ & -8.023 & -3.026 & -5.546 & -7.040 \\
& $(6.744)$ & $(4.792)$ & $(4.941)$ & $(5.135)$ & $(4.818)$ & $(5.993)$ \\
Retained Earnings/Assets 2007 & 0.765 & 0.746 & -1.324 & 2.055 & 0.573 & 2.005 \\
& $(2.450)$ & $(2.276)$ & $(2.664)$ & $(2.789)$ & $(2.322)$ & $(2.873)$ \\
Acc. Payable/CGS 2007 & $0.0342^{*}$ & $0.0299^{* *}$ & 0.0192 & $0.0333 *$ & $0.0278^{*}$ & 0.0293 \\
& $(0.0197)$ & $(0.0151)$ & $(0.0157)$ & $(0.0170)$ & $(0.0153)$ & $(0.0191)$ \\
Exports/Sales 2007 & -3.677 & -3.205 & -2.412 & -3.290 & -3.294 & -3.519 \\
& $(2.884)$ & $(2.970)$ & $(3.075)$ & $(3.050)$ & $(2.994)$ & $(7.878)$ \\
I_Quad1 & $8.150^{* * *}$ & $6.096^{* * *}$ & $6.537 * * *$ & $5.289^{* * *}$ & $6.286^{* * *}$ & $5.893 * * *$ \\
& $(2.152)$ & $(1.703)$ & $(1.766)$ & $(1.912)$ & $(1.730)$ & $(2.261)$ \\
I_Quad2 & $13.39 * * *$ & $8.898^{* * *}$ & $9.073^{* * *}$ & $5.508 * * *$ & $8.774 * * *$ & $8.359^{* * *}$ \\
& $(2.220)$ & $(1.759)$ & $(1.809)$ & $(1.950)$ & $(1.772)$ & $(2.281)$ \\
I_Quad3 & 0.726 & -0.550 & -0.751 & -2.381 & -0.824 & 0.0244 \\
& $(1.735)$ & $(1.499)$ & $(1.547)$ & $(1.656)$ & $(1.518)$ & $(2.157)$ \\
Constant & $-25.39 *$ & $-26.92^{* * *}$ & $-26.53 * * *$ & $-29.06 * * *$ & $-28.01 * * *$ & $-28.37 * *$ \\
& $(13.39)$ & $(9.914)$ & $(9.832)$ & $(10.89)$ & $(9.778)$ & $(11.77)$ \\
Observations & & & & & & \\
R-squared & 1,953 & 3,181 & 3,165 & 2,614 & 3,269 & 2,218 \\
\hline
\end{tabular}

Standard errors in parentheses $* * * \mathrm{p}<0.01,{ }^{* *} \mathrm{p}<0.05,{ }^{*} \mathrm{p}<0.1$

Notes: Columns (1)-(6) replicate the results shown in column (2) of Table 2 while removing one country at a time from the sample (i.e. China, India, Indonesia, Malaysia, Taiwan and Thailand). As in Table 2 , we use dummy variables to control for firm size, industry and country effects, but do not report their coefficient estimates. 
Table 13. Determinants of Trade Credit:

\section{Robustness to Sample Composition (Countries)}

Dependent variable: Change in the Acc. Payable/Cost of Goods Sold Ratio, 2008:Q3-2009:Q1

\begin{tabular}{lcccccc}
\hline & $(1)$ & $(2)$ & $(3)$ & $(4)$ & $(5)$ & $(6)$ \\
\hline VARIABLES & & & & & & \\
\hline & -0.0928 & -0.237 & -0.129 & -0.386 & -0.176 & -0.0161 \\
Quick ratio $_{2007}$ & $(0.465)$ & $(0.384)$ & $(0.395)$ & $(0.458)$ & $(0.400)$ & $(0.478)$ \\
Short-term debt/Assets 2007 & $16.33^{* * *}$ & $16.37^{* * *}$ & $17.47^{* * *}$ & $19.11^{* * *}$ & $17.36^{* * *}$ & $16.93^{* *}$ \\
& $(5.934)$ & $(5.293)$ & $(5.667)$ & $(5.976)$ & $(5.497)$ & $(6.730)$ \\
External Finance/Assets 2007 & $13.52^{*}$ & $10.92^{*}$ & 5.774 & 9.661 & 9.004 & 1.780 \\
& $(7.140)$ & $(5.864)$ & $(6.038)$ & $(6.330)$ & $(5.805)$ & $(6.900)$ \\
Retained Earnings/Assets 2007 & 1.942 & 0.330 & -0.269 & -0.746 & 0.418 & 1.348 \\
& $(2.107)$ & $(2.025)$ & $(2.593)$ & $(2.406)$ & $(2.126)$ & $(2.314)$ \\
Exports/Sales 2007 & $-6.716^{* * *}$ & $-4.750^{*}$ & $-4.796^{*}$ & -3.807 & $-4.395^{*}$ & -3.417 \\
& $(2.517)$ & $(2.544)$ & $(2.609)$ & $(2.656)$ & $(2.566)$ & $(5.317)$ \\
Constant & 2.760 & 6.471 & 11.28 & 18.59 & 10.41 & 20.62 \\
& $(11.69)$ & $(12.18)$ & $(11.01)$ & $(14.00)$ & $(11.09)$ & $(13.89)$ \\
Observations & & & & & & \\
R-squared & 1,147 & 1,497 & 1,434 & 1,167 & 1,519 & 1,046 \\
& 0.078 & 0.068 & 0.048 & 0.102 & 0.062 & 0.067 \\
\hline
\end{tabular}

Standard errors in parentheses $* * * \mathrm{p}<0.01,{ }^{* *} \mathrm{p}<0.05,{ }^{*} \mathrm{p}<0.1$

Notes: Columns (1)-(6) replicate the results shown in column (2) of Table 3 while removing one country at a time from the sample (i.e. China, India, Indonesia, Malaysia, Taiwan and Thailand). As in Table 3, we use dummy variables to control for firm size, industry and country effects, but do not report their coefficient estimates. 
Figure 1. Exports Relative to GDP

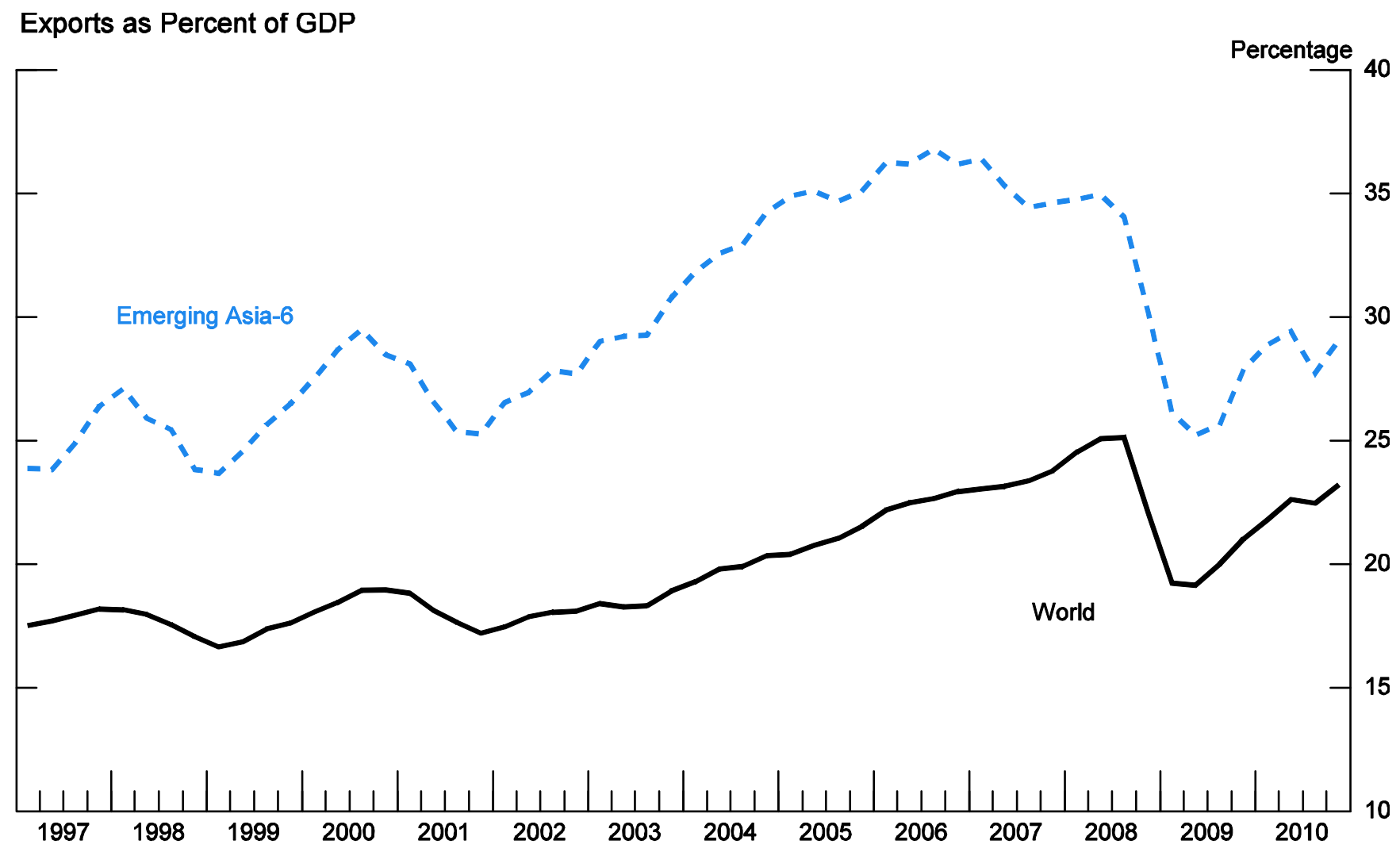

Source: Haver Analytics

Source: Haver Analytics, quarterly nominal GDP and exports (in US\$, seasonally-adjusted).

Note: "Emerging Asia-6" includes the six countries in our sample: China, India, Indonesia, Malaysia, Taiwan, and Thailand. "World" comprises of: Australia, Austria, Belgium, Canada, China, Denmark, Finland, France, Germany, Hong Kong, India, Indonesia, Italy, Japan, Korea, Malaysia, Netherlands, New Zeeland, Norway, Portugal, Spain, Sweden, Switzerland, Taiwan, Thailand, the United Kingdom and the United States. 
Figure 2. Aggregate vs. Firm-Level Data
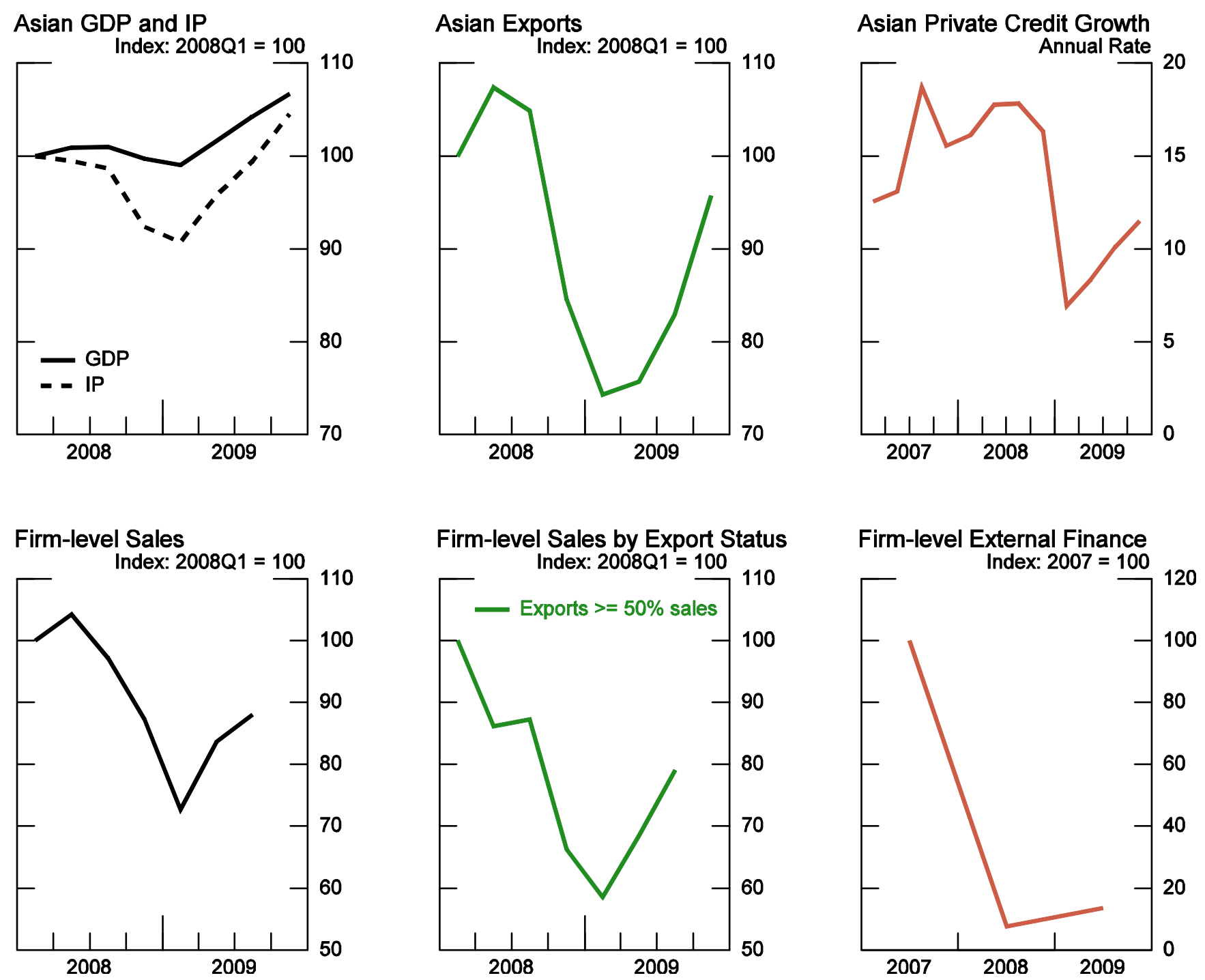

Sources: Haver Analytics (aggregate data) and Worldscope (firm-level data).

Notes: For the aggregate data (top panels), we use real GDP (in local currencies, seasonally-adjusted) and industrial production (IP); private credit growth (computed as the $\mathrm{q} / \mathrm{q}$ annualized growth rate of outstanding private credit in local currencies, non seasonally-adjusted); and exports (in nominal US\$, seasonally-adjusted) for six emerging Asian economies (China, India, Indonesia, Malaysia, Thailand and Taiwan). We normalize the GDP, IP and exports series relative to 2008:Q1, and take non-weighted averages of the resulting indices for the six countries. For private credit, we use: (1) China: Uses of credit funds of Financial Institutions, 100 Mil. Yuan, NSA; (2) India: Domestic Credit: Commercial Sector, NSA, Millions Rupees; (3) Indonesia: Commercial Bank Credit, NSA Bil. Rupiahs; (4) Malaysia: Banking Sector: Claims on Private Enterprises, NSA, Mil. Ringgit;

(5) Taiwan: Loans/Investments of Major Financial Institutions: Claims on Private Sector, NSA, 100 Mil. NT\$;

(6) Thailand: Depository Corporations Survey: Claims on Other Sectors, NSA, Mil. Baht.

For the firm-level data (bottom panels), we report medians computed across the full sample of firms from the six emerging Asian countries (China, India, Indonesia, Malaysia, Thailand and Taiwan), and report the values relative to 2008:Q1. For firm-level external finance (bottom-right panel), the data is available at the annual frequency only. 


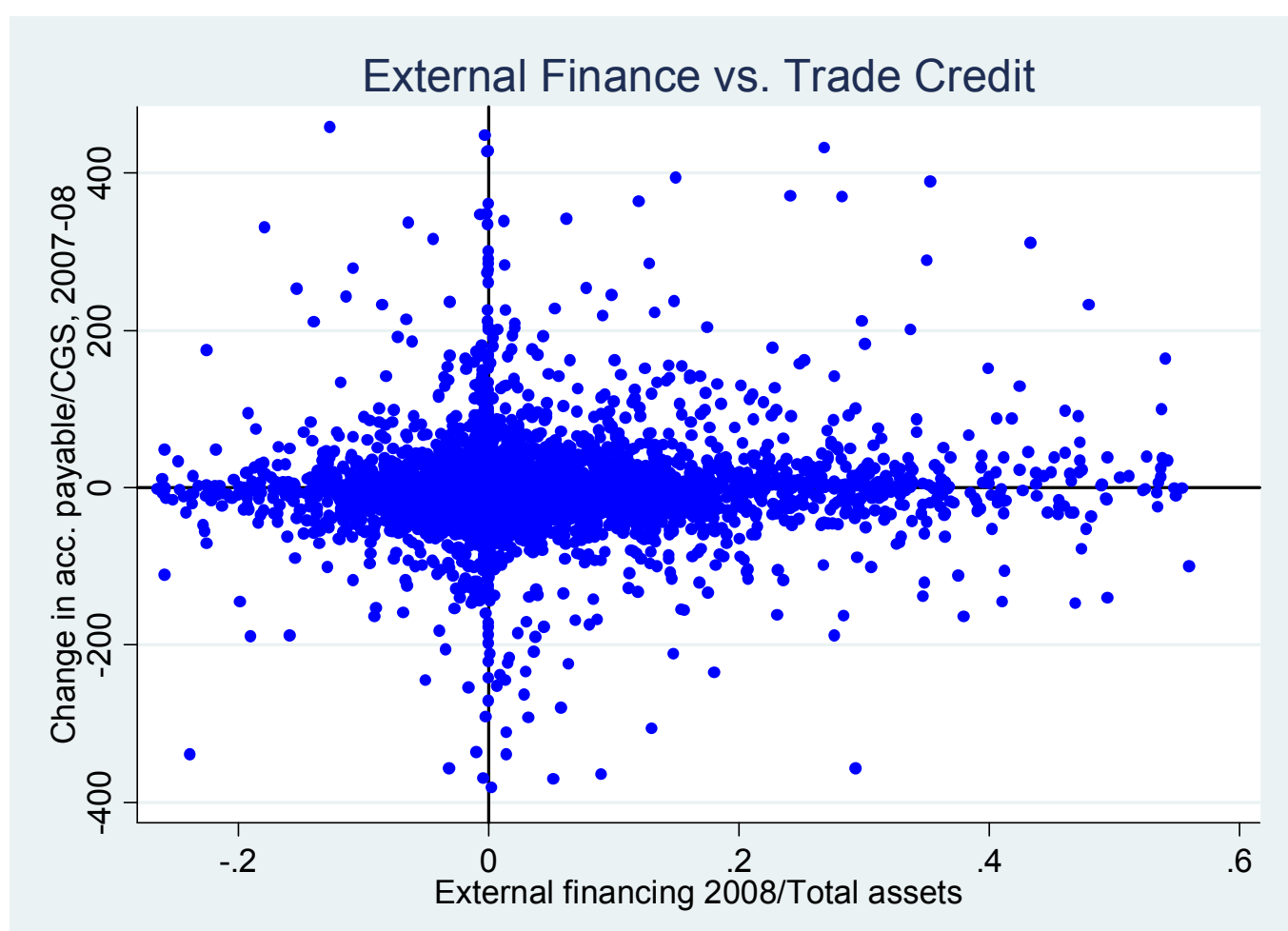

Source: Worldscope firm-level data. The sample includes firms from China, India, Indonesia, Malaysia, Taiwan and Thailand.

Note: On the horizontal axis, the amount of external finance (available at the annual frequency only) normalized by total assets measures the flow of firm financing from outside sources in 2008, such as the issuance and/or retirement of stock and debt. Negative values of external finance correspond to firms that repurchased equity or experienced declines in their outstanding debt during the crisis. On the vertical axis, the difference in the stock of accounts payable between 2007 and 2008 normalized by the cost of goods sold shows the change in trade credit received from suppliers during the crisis. Positive values correspond to firms that obtained more trade credit in 2008 relative to the previous year 